\title{
Antennule development during copepodite phase of some representatives of Harpacticoida (Copepoda, Crustacea)
}

\author{
Hans-Uwe Dahms \\ Universität Oldenburg, Fachbereich 7, Arbeitsgruppe Zoomorphologie, D-2900 Oldenburg, F.R.G.
}

Keywords: morphology, postembryonic development, taxonomy, phylogeny, developmental pattern, Harpacticoida

\begin{abstract}
The copepodite antennule development of representatives of 6 harpacticoid families is studied and discussed in detail and that of $\mathbf{8}$ genera of harpacticoids from 7 families is schematically illustrated. Twenty-seven genera out of 17 harpacticoid families are compared on the basis of own investigations and data from the literature. The origin of newly formed segments can be determined by seta numbers of segments, relative segment length, furrows indicating previous articulations and by the position of the segment which bears the proximal aesthetasc. There are 2 zones of segment formation, both located in the middle part of the first antenna. Normal segment formation takes place distally from the second, aesthetasc-bearing segment from C I to C II and proximally of it from C III to C IV. At least in some species sexual dimorphism of first antennae is present from $\mathrm{C}$ II onwards. Females practically show the adult antennular state at $C$ $\mathrm{V}$ whereas males undergo important changes from $\mathrm{C} \mathrm{V}$ to $\mathrm{C} \mathrm{VI}$ with proximal addition of segments, and often with distal fusions and formation of a unique armature due to adaptations in clasping behaviour. There are specific formation patterns in certain taxonomic groups. E.g. Harpacticidae, Canthocamptidae, Canuellidae and Longipediidae deviate in antennule formation from the rest of Harpacticoida. A higher number of antennular setae of C I which in most of the cases are reduced in C II may be interpreted as indicating an ancestral multisegmented antennule for Harpacticoida.
\end{abstract}

\section{Zusammenfassung}

Die Entwicklung der Antennula von Harpacticidenarten aus 6 Familien wird beschrieben und die von 8 Gattungen aus 7 Familien der Harpacticoida schematisch dargestellt. Auf der Grundlage eigener Untersuchungen und Angaben aus der Literatur wird die Entwicklung dieser Extremität bei 27 Gattungen aus 7 Familien der Harpacticoida verglichen. Der Ursprung von neu gebildeten Gliedern wird erkennbar an: der Borstenanzahl der Glieder, der relativen Länge der Glieder, frühzeitigen Anzeichen von Abgliederungen durch Furchung der Kutikula und der Lage des Gliedes, das den proximalen Aesthetasken trägt. Es gibt zwei Zonen der Gliederneubildung, die beide in der Mitte der Antennula liegen. I. d. R. wird ein Glied distal vom zweiten, Aesthetask tragenden Glied vom Copepodit I zum Copepodit II und proximal von diesem vom Copepodit III zum Copepodit IV abgegeben. Zumindestens bei einigen Arten ist Sexualdimorphismus der Antennulae vom Copepoditen II an erkennbar. Die Weibchen erreichen den Adultzustand der Antennula weitgehend im C V-Zustand. Bei den Männchen tritt hingegen ein starker Formwechsel vom Copepodit V zum Adultus mit proximaler Gliederneubildung, oftmals mit distalen Verschmelzungen und der Bildung einer charakteristischen Bewehrung als Anpassung an das Präkopula-Verhalten auf. Spezielle Bildungsmuster der Antennulaglieder sind auf bestimmte Gruppen beschränkt. So weichen die Longipediidae, Canuellidae, Harpacticidae und Canthocamptidae dabei von der Antennulaentwicklung der restlichen Harpacticoida ab.

Es wird mit Hilfe von Rekapitulationsmerkmalen versucht aufzuzeigen, daß die Gliederanzahl der Harpacticidenantennula ein Merkmal in reduziertem Zustand ist.

\section{Introduction}

Among postembryonic characters growth and differentiation of copepodite first antennae of Harpacticoida have as yet received little attention. This is astonishing as these uniramous almost cylindrical appendages are characterized by peculiar structures and morphogenetic patterns of which some are characteristic for all harpacticoids whereas others are differing according to taxonomic groups.

The developmental history of this appendage of 
calanoid copepods in particular has been the subject of several detailed studies (Claus, 1893; Giesbrecht, 1892; Oberg, 1906; Gurney, 1931). These authors have tried to homologize antennular segments in order to elucidate the primitive status of the Calanoida and to reconstruct the ancestral first antenna of Copepoda.

Haq (1965) was the first to homologize the antennular segments in the copepodite phase of a representative of the Harpacticoida. Later Itô (1970) pointed out the possible phylogenetic importance of antennular formation patterns.

In the present study an attempt is made to homologize segments during the postnaupliar development of 8 species and genera and to compare the developmental patterns of species belonging to various genera and families of the Harpacticoida. As a result information on common morphogenetic characters will be obtained as well as an idea about the ancestral antennular structure within the group.

\section{Material and methods}

The postnaupliar stages used in this study were obtained from several sites. Copepodids of Thalestris longimana Claus, 1863 were collected from $\mathrm{Ce}$ ramium rubrum (Huds.) C. Ag. (Rhodophyta, Ceramiaceae) of the rocky intertidal of Helgoland (North Sea, German Bight). Copepodids of Tegastes clausi Sars, 1904 were obtained from sublittoral holdfasts of Laminaria hyperborea (Gunnerus) Foslie (Phaeophyta, Phaeophyceae) and copepodids of Alteutha interrupta (Goodsir, 1845) from plankton samples taken closely above the bottom after stormy weather (Helgoland-Reede). Egg-sac carrying females of Ectinosoma melaniceps Boeck, 1864 were isolated from the upper littoral zone of the NW-intertidal of Helgoland. Ovigerous females of Heterolaophonte minuta (Boeck, 1872) were collected from the muddy intertidal of Mellum island (North Sea, German Bight) in summer 1986 and reared in the laboratory as described by Dahms (1986) for another species.

Ovigerous females of Tisbe gracilis (T. Scott, 1895) were isolated from the Ostend Sluice Dock in 1976 and reared since then in the laboratory by $M$.
Bergmans; those of Drescheriella glacialis Dahms \& Dieckman, 1987 were obtained from Antarctic fast ice in 1985 and kept since then in culture in a cooling-container. Copepodids of Macrosetella gracilis (Dana, 1848) were investigated from samples taken in the central Red Sea by R.V. Valdivia in November 1980.

Stages of the following species have been analyzed but the results are considered in table 1 only: copepodids of Canuella perplexa T. \& A. Scott, 1893 and Paraleptastacus espinulatus Nicholls, 1935 were collected from a sandy beach of Helgoland-Düne. Gravid females of Harpacticus obscurus T. Scott, 1895 were collected from the littoral zone of Gullmarfjord (Sweden), those of Tachidius discipes Giesbrecht, 1881 from a muddy intertidal sandflat of the Jade-Busen (German Bight), and those of Bryocamptus pygmaeus (Sars, 1862) were taken from a swamp in NW-Germany (Dahms, 1987b). Copepodids of Parastenocaris vicesima Klie, 1935 were obtained from groundwater samples taken along a small stream near Lake Constance (southern Germany).

Specimens fixed in formalin were transferred to W 15 (embedding medium of C. Zeiss Company) for microscopical investigation. First antennae were studied with an oil-immersion lens and figured with the aid of a camera lucida.

It turned out to be useful not to dissect the antennules to ensure similar orientation of them in the different stages. Only in adults dissection became necessary in some cases. The specimens were pushed till the first antennae were oriented in one plane. Measurements were made as follows: length is given as the distance from the proximal border line of the 2nd segment to the end of distal segment; width is given as maximal breadth of the second segment. The first segment has not been included in the measurements because its proximal part is often destroyed during dissection and on whole mounts the proximal border line is difficult to make out exactly. Although 3-5 specimens of each stage have always been checked for qualitative characters, only the figured one has been measured.

Sexual dimorphism is determined only in the first antennae. It is possible that sexual dimorphism may become apparent earlier on the basis of other char- 
acters, but these have been omitted here. When a segment budds off from another one from one stage to the next, it is difficult to decide which of the two is the new one. In the following, the segment with a new segment number, and in case of proximal segregation the proximalmost, is termed "new".

The schematic diagrams of the development of first antennae (figs. 13, 14) present the developmental formation of the antennular segments and setae/aesthetasc number. Numbers always include the aesthetasc. In cases where the exact seta number was difficult to make out (especially in adult males) no number has been given. Table 1 provides information on segment number of first antennae and the location of the proximal aesthetasc for all those harpacticoid species for which reliable information is available in the literature on the postnaupliar development of this appendage.

References - if not mentioned in the text - are given in the table. Abbreviations used throughout the text and figures are: C I - C VI (=adult) = first through sixth copepodite stage; $P 4=$ fourth swimming leg.

\section{Description of first antennae}

As the number of setae and aesthetascs is given in the diagrams (figs. 13,14), only segment characteristics (segment number, size, ornamentation, way of formation), changes in setae composition as well as structure, and points of special interest are given in the text.

\section{Ectinosoma melaniceps (ECTINOSOMATIDAE)}

The right first antennae of this species are drawn in ventral view (except adult female, given in dorsal view; fig. 2), with the outer margin showing to the top of the page (figs. 1, $2-$ female $\mathrm{C} \mathrm{V}$ ) or to its left side respectively (fig. 2). Measurements are taken from the base of 2 nd segment to the base (!) of the terminal process.
Copepodid I

First antenna (figs. 1,13$)$ of 3 segments $(21 \times 9 \mu \mathrm{m})$. Third segment twice as long as 2 nd.

All 3 setae of 1st segment bare and situated at outer border. Proximal aesthetasc of 2 nd segment situated half-way on inner side and not accompanied by a seta (i.e. not sharing a common base with a seta). The 2 inner setae of this segment are spinulose on both sides. Third segment subdivided distally. Proximal part with 8 bare setae of different length. The 2 dorsolateral ones are spinulose. A process of the outer distal corner bears a long terminal aesthetasc on inner margin and 3 bare setae of similar length, one of which originates subterminally.

\section{Copepodid II}

First antenna (fig. 1) 4-segmented $(28 \times 11 \mu \mathrm{m})$. The newly formed 3 rd segment has been splitt off from the 2 nd segment. This is concluded from the distal position this time of the proximal aesthetasc, the shortening of the 2nd segment, and the unchanged setae configuration of the distal segment.

The 2 smaller setae of 1 st segment of C I are totally reduced so that only the one at outer distal corner is retained. Three new setae are formed on 2 nd segment. The former and the spinulose seta of $\mathrm{C} \mathrm{I}$ is now bare. The aesthetasc has become situated on top of a ventrodistal process and is accompanied by a bare seta. Another seta is located at dorsal base of this process. The newly formed 3rd segment is unarmed. The 4th segment has not undergone any change, except for a slight size difference, and looks like 3rd segment of C I; 2 spinulose setae on outer margin are the only spinulose ones at this stage.

\section{Copepodid III}

First antenna (fig. 1) of 4 segments $(35 \times 12 \mu \mathrm{m})$. Second segment has become elongate.

Seta on outer distal corner of 1st segment reduced in length and width. Fourth segment with 2 more setae, 1 midlength on dorsal side and one midlength on outer margin.

\section{Copepodid IV}

First antenna (fig. 1) of 5 segments $(39 \times 13 \mu \mathrm{m})$. 
Table 1. Ontogenetic development of A 1 segmentation of harpacticoid copepodids (sexual dimorphism judged from structure of first antennae alone; 4/3: segment number/segment bearing proximal aesthetasc); \#: number of segments not definitely known or indistinctly separated; ?: information lacking; (...): second reference)

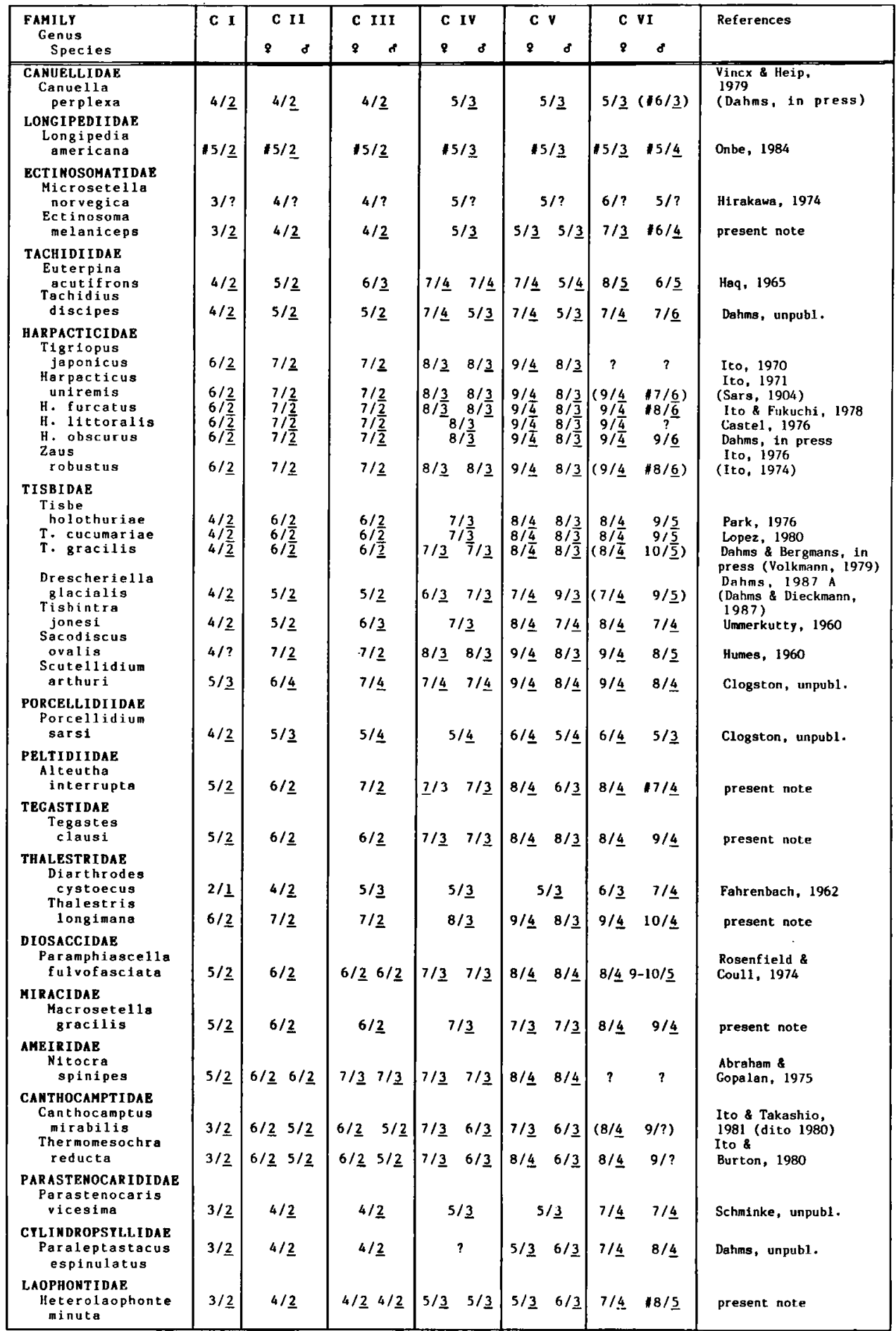




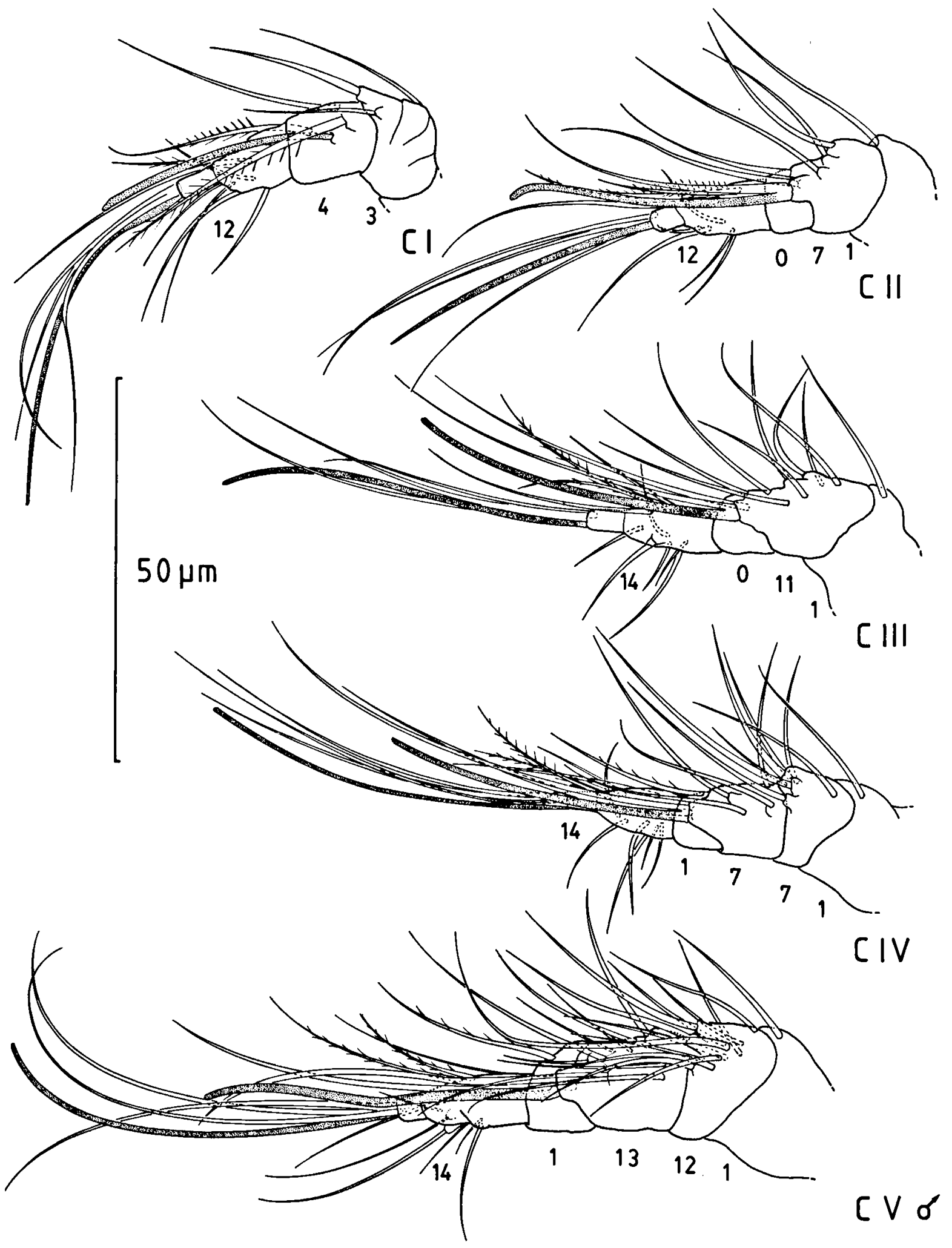

Fig. I. Ectinosoma melaniceps. Development of first antennae of copepodids I-V. 


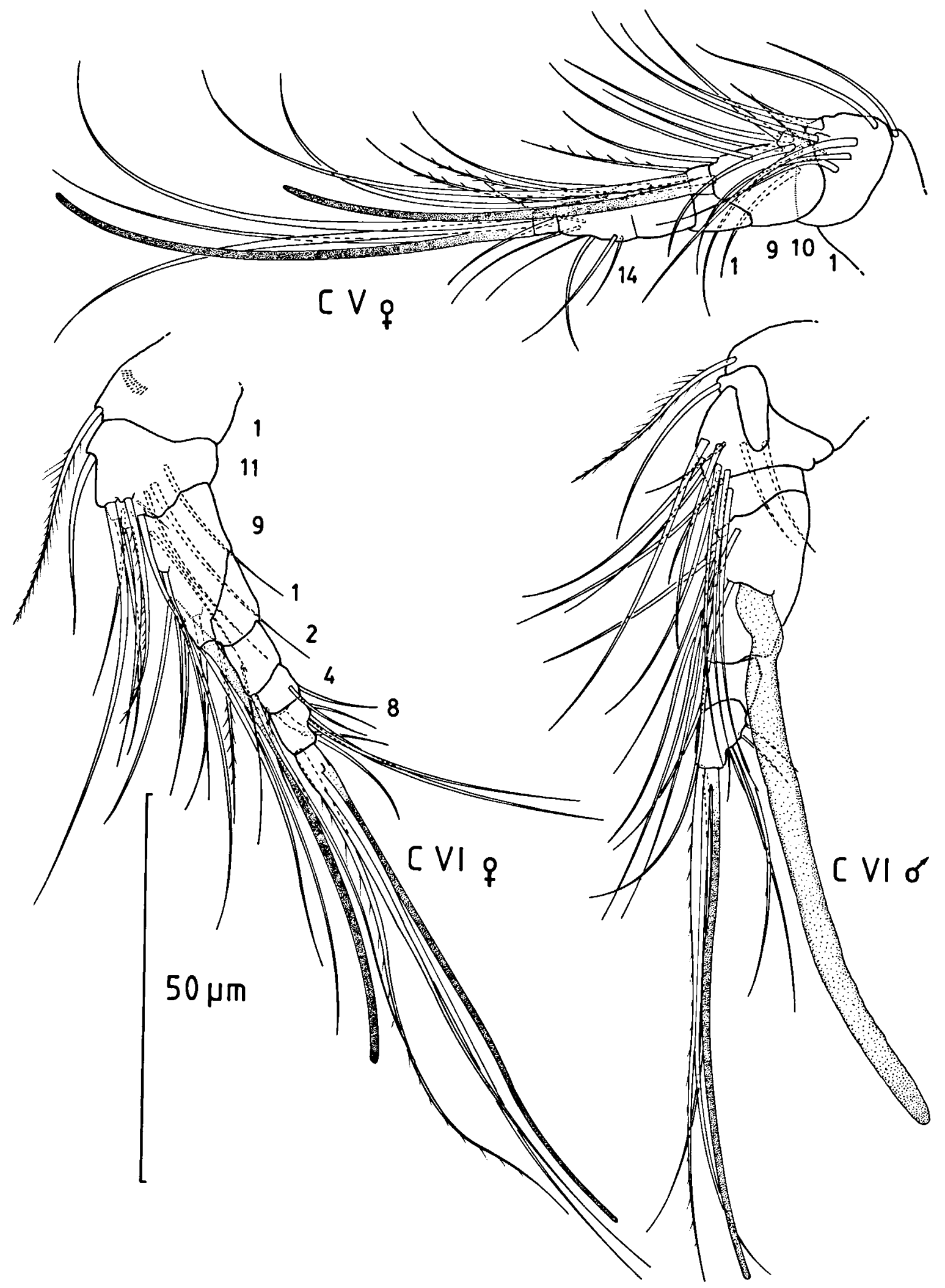


The newly formed 2 nd segment has split off proximally from 2 nd segment of C III. This is concluded from the reduced seta number of the segment bearing the proximal aesthetasc and from the unchanged structure of the 1st segment.

It is difficult to decide whether any of the 7 setae on the new 2nd segment are new or whether all of them have been taken over from the 2 nd segment of C III. The seta number of both the 2 nd and 3 rd segment has increased from 11 (2nd segment of C III) to 14 on the homologous segments (2nd plus 3rd segment) of C IV. The 4th segment with 1 seta, spinulose along the inner side, subdistally on outer margin.

\section{Copepodid V}

First antenna (figs. 1,2) of 5 segments in both sexes but sexually dimorphic in setation. The 4 th and 5 th segments have increased in length. Terminal process of 5th segment has proportionally decreased in size. A furrow is detectable in the proximal third of the 5 th segment.

First antenna of male (fig. 1) $(45 \times 16 \mu \mathrm{m})$. Second segment bears 12 setae; 3rd segment bears 13 setae/aesthetasc.

First antenna of female (fig. 2) $(43 \times 16 \mu \mathrm{m})$. Second segment bears 10 setae; 3rd segment bears 9 setae/aesthetasc.

\section{Copepodid VI}

First antennae (fig. 2) of 7 segments in female and of 6 segments in male. In both sexes the single seta of the 1st segment as well as the seta of the terminal process which originates subterminally in $\mathrm{C} \mathrm{V}$ have become spinulose. The latter also originates at base of the process in adult stage.

First antenna of male $(53 \times 17 \mu \mathrm{m})$. The $3 \mathrm{rd}$ segment of $\mathrm{C} \mathrm{V}$ male has proliferated another proximal segment ( 3 rd segment of male C VI) and at the same time is fused with the former 4th segment. This is concluded from the now midlength position of the proximal aesthetasc. The furrow of the 5th segment of $\mathrm{C} \mathrm{V}$ is interpreted as marking the be- ginning of a separation into two segments. Therefore the new 5th segment of the adult male represents the proximal part, and the 6th segment the distal part of the former 5th segment. The first antenna geniculates between the 4th and 5th segment. The adult male is grasping the inner side of the females base of the caudal setae from above and twisting its antennae outwards around the ventral side. The 2 nd segment is characterized by a saddlelike structure on outer ventral margin bearing 1 outer seta. The proximal aesthetasc has lost its process and is separated from the seta with which it shares a common base from C II to C V. The fate of the seta on the dorsal side of this process which does persist in the female is unclear in the male.

First antenna of female $(48 \times 16 \mu \mathrm{m})$. The 5 th segment of $\mathrm{C} \mathrm{V}$ has become divided into $3 \mathrm{seg}$ ments; the proximal one is twice as long as each of the 2 distal ones. This is concluded from the almost unchanged proximal segments and from the fact that the setae/aesthetasc number of the three newly formed terminal segments together is the same (viz. 14) as on the distal segment of $C V$. One of the setae at the outer distal corner of the 2 nd segment has become spinulose.

\section{Tegastes clausi (TEGASTIDAE)}

The left first antennae of this species have been drawn in lateral view (except female C VI which is shown in ventrolateral view), the dorsal side on top (figs. 3, 4) except C I (fig. 3) where the ventral side is drawn on top. The segments lack any cuticular peculiarities or ornamentation.

\section{Copepodid I}

First antenna (figs. 3, 13) 5-segmented $(42 \times 15$ $\mu \mathrm{m})$. Distal segment twice as long as 3rd and 4th together. All setae/aesthetasc of at least the first three segments arise from a small basal protuberance; all setae bare.

Segment 1 with 1 seta on outer distal corner. 


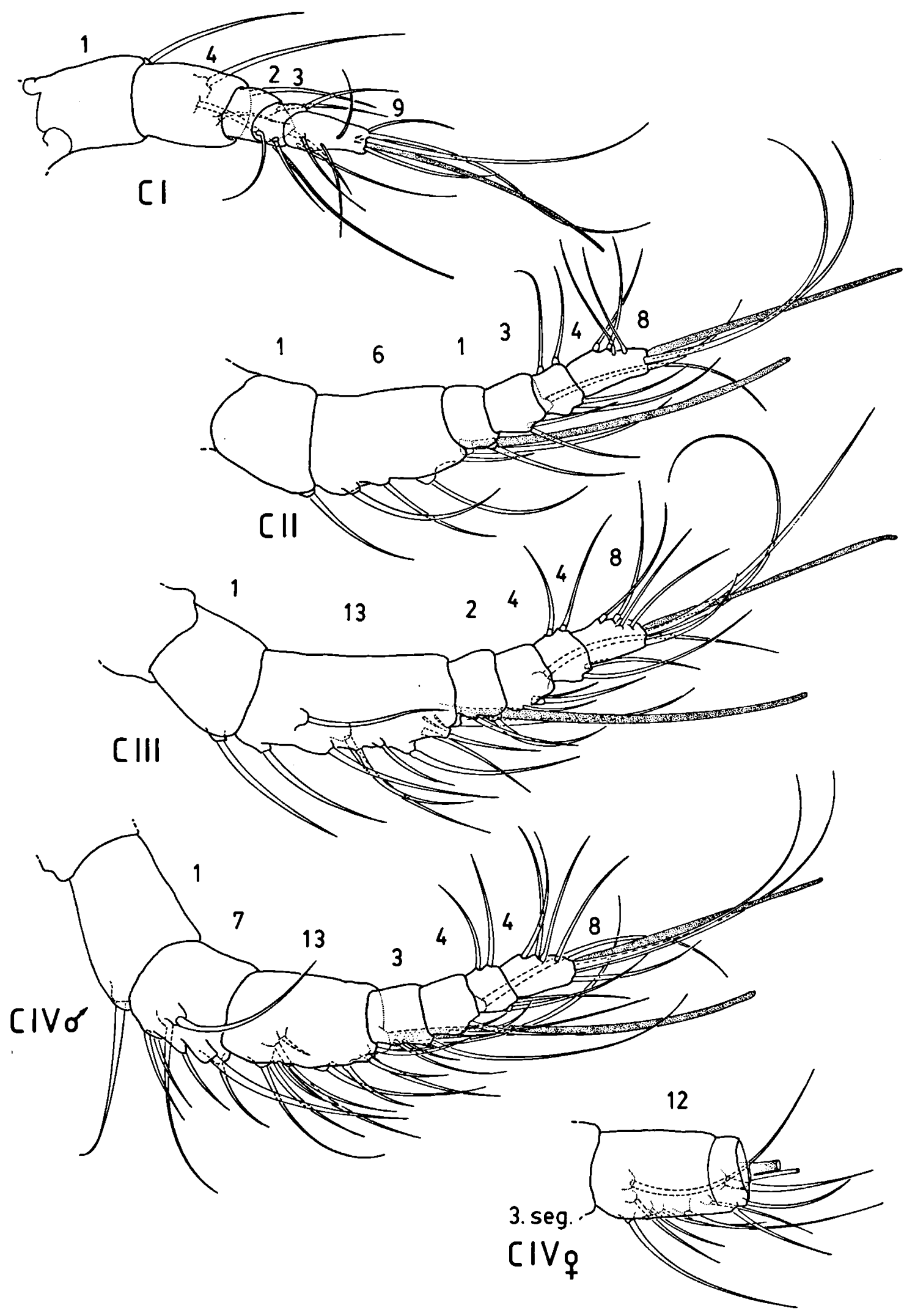


Second segment with 2 setae midlength on ventral side, 1 seta on ventrolateral margin and 1 aesthetasc which is seta-like at base and becomes broader and granular in appearance in distal two-thirds. Segment 3 with 2 setae, one subdistally and the other on a pointed ventrodistal protrusion. Three setae on 4 th segment. Segment 5 with 9 setae; 4 of them situated midlength on dorsal side, and 5 distally. Seta at outer distal corner smallest. The seta next to it arises from a subterminal protuberance and is as long as the accompanying seta of the long and slender terminal aesthetasc; the latter two confluent at base. Seta at inner distal corner half as long as one of aforementioned 2 setae.

\section{Copepodid II}

First antenna (fig. 3) of 6 segments $(61 \times 17 \mu \mathrm{m})$. The 3rd segment is new and has been split off distally by the 2 nd segment which bears the proximal aesthetasc. This is deduced from the now distal position of the aesthetasc and from the fact that the 4th segment of C II can be homologized with the 3rd segment of $\mathrm{C} \mathrm{I}$ because of its pointed ventrodistal protrusion bearing a seta. The 2 nd segment has become elongate. Second segment bears 4 setae along ventrolateral margin; distalmost of those small and situated near base of setae/aesthetasc complex. From now on the ventrodistal aesthetasc shares a common base with another seta. The newly formed 3rd segment bears 1 seta on dorsal side. Segment 4 has 2 setae midlength of which one must be new and a third on the pointed ventrodistal protrusion. Segment 5 with 2 setae on both dorsal and ventral sides. Ventral 2 articulated at base. Midlength dorsal seta is new. At least the 2 proximal setae on inner margin of 6th segment have become articulated at base, and one of distal setae, the innermost near terminal aesthetasc, has been completely reduced.

\section{Copepodid III}

First antenna (fig. 3) of 6 segments as in preceding stage $(69 \times 17 \mu \mathrm{m})$. Segment 2 considerably increased in length, as long as 4 distal segments together. It bears 13 setae/aesthetasc on outer margin. Segment 3 has developed additional proximal dorsal seta arising from protuberance. Segment 4 has new seta midlength.

\section{Copepodid IV}

First antenna (fig. 3) of 7 segments in both sexes but sexually dimorphic in setation. The newly formed 2nd segment has been given off proximally by 2 nd segment of C III. This is concluded from the unchanged structure of the 1st segment, the decreased length of the 2 nd segment and the position of the proximal aesthetasc. The 3 distal segments do not undergo marked changes during the subsequent stages except the adult male. Segment 1 increased in length and nearly as long as segment 3 . Single seta of 1 st segment has more subdistal position. The articulation at base of the 2 setae on inner margin of 6th segment and of proximal 2 setae of 7 th segment hardly discernible. Nevertheless the 2 setae on ventral side of penultimate segment and all 4 setae midlength on distal segment distinctly articulated at base in adult stage.

First antenna of male $(78 \times 19 \mu \mathrm{m})$. Setae/aesthetasc number has increased from 13 (2nd segment of C III) to 20 (2nd plus 3rd segment of male C IV). Segment 4 has developed third seta on dorsal margin.

First antenna of female $(83 \times 16 \mu \mathrm{m})$. There are sexually dimorphic characters only on 3rd segment (only 12 setae/aesthetasc in the female, 13 in the male) and in a slight subdistal furrow preluding the segregation in the next stage.

\section{Copepodid V}

First antenna (fig. 4) of 8 segments in both sexes but sexually dimorphic in setation. A new 4th segment has been formed. The single seta on the dorsodistal corner of 1st segment has become slightly spinulose.

First antenna of male $(101 \times 19 \mu \mathrm{m})$ characterized by enlongate 2 nd and 3 rd segments, 3rd bearing the proximal aesthetasc. The new 4 th segment split off distally by the proximal aesthetasc bearing segment. This is concluded from the unchanged seta-

Fig. 3. Tegastes clausi. Development of first antennae of copepodids I - IV. 


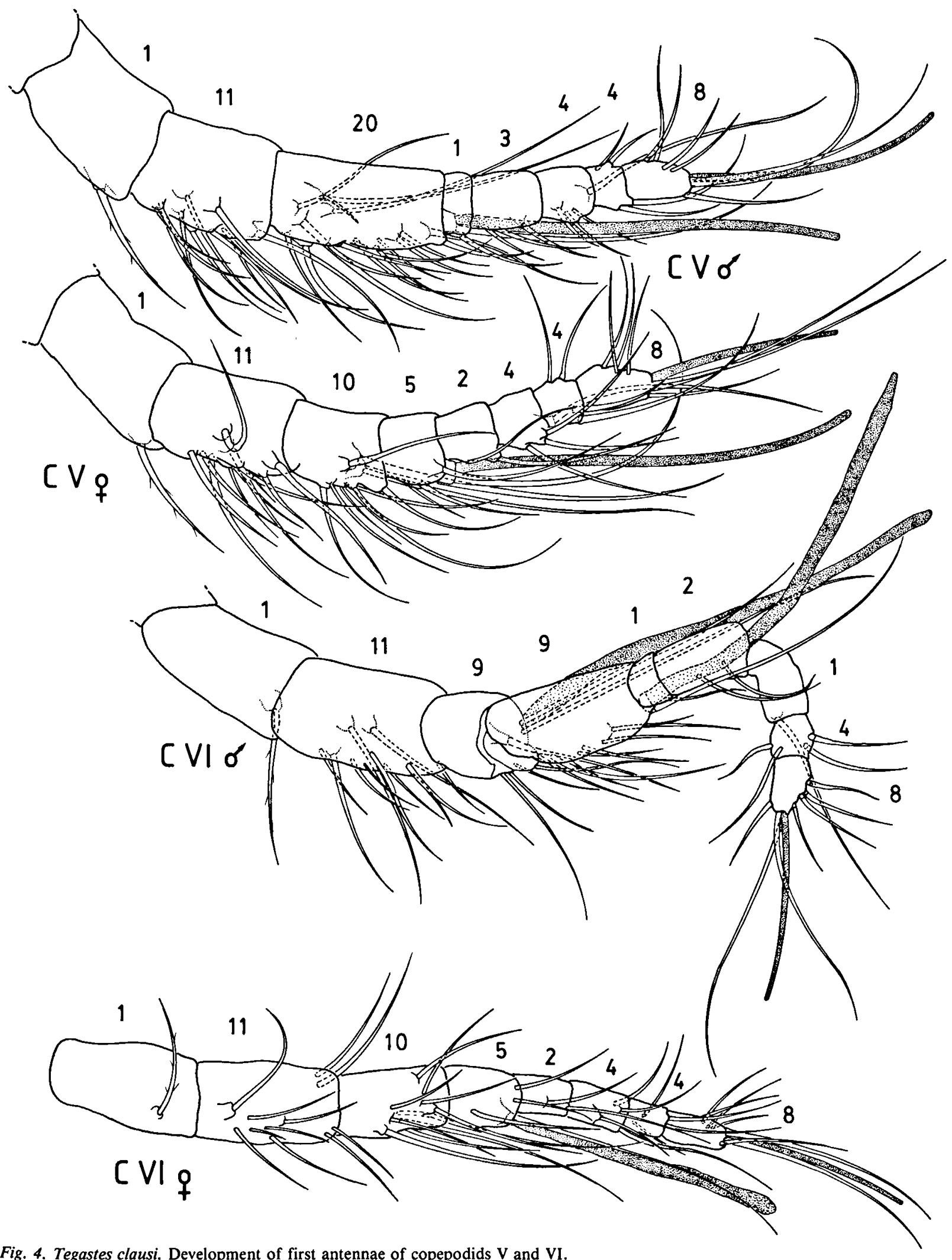

Fig. 4. Tegastes clausi. Development of first antennae of copepodids V and VI. 
tion pattern of the 4th segment of C IV; new 4th segment bears 1 seta on outer margin.

First antenna of female $(92 \times 17 \mu \mathrm{m})$ : newly formed segment split off proximally by proximal aesthetasc-bearing segment. Segment 5 (homologous to segment 4 of C IV and to 5 of male C V) has reduced one of the 2 setae situated midlength (this seta persists in male $\mathrm{C} \mathrm{V}$, whereas it is reduced in the adult male).

\section{Copepodid VI}

First antenna (fig. 4) of 9 segments in male and of 8 segments in female.

First antenna of male $(109 \times 15 \mu \mathrm{m})$ with elongate 1 st and 2nd segments. Segment 3 of male C V divided in the proximal third. Therefore the proximal aesthetasc characterized by the seta with which it shares a common base is now situated on the outer distal margin of the 4th segment. The most proximal aesthetasc of this stage on dorsal margin of 3rd segment has developed de novo as is shown by Dahms (1988). Segment 6 has reduced one of the three setae on the outer margin. Both 6 th and 7 th segments slightly concave on dorsal margin. Segment 7 widened distally since the geniculation point is in between; it has reduced the $\mathbf{3}$ setae on dorsal margin retaining only the one on dorsodistal corner. These setal reductions of the 6 th and 7 th segments between which geniculation takes place are probably adaptations to avoid interference of setae in grasping mobility. Terminal segment has become tapered. The male clasps the female's caudal setae.

First antenna of female $(89 \times 12 \mu \mathrm{m})$ has same segmentation and setation as in female $\mathrm{C} \mathrm{V}$. However, it is slightly reduced in size and cuticularization has increased.

\section{Alteutha interrupta (PELTIDIIDAE)}

The left first antennae are drawn in outer lateral view. The segments (except the 1st segment of $\mathrm{C}$ II-C VI and adult males) lack any ornamentation. The setae usually are bare except those described in the text.

\section{Copepodid I}

First antenna (figs. 5, 13) 5-segmented $(64 \times 27$ $\mu \mathrm{m})$.

Segment 1 characterized by 2 notches, bearing a single seta on the outer distal corner. Segment 2 bears 2 setae midlength on dorsal side, of which distal one is stippled with traces of spinules. Proximal single aesthetasc, and a seta nearby, originate from cuticular subdistal protuberance. Aesthetasc comparatively long, nearly reaching end of terminal aesthetasc. Segment 3 armed with 2 dorsal setae originating on a dorsolateral particular protuberance each, the dorsalmost spinulose. Segment 4 bears 1 seta on protuberance of dorsal corner and 2 setae articulated at base on ventral side, one proximally and the other on distal corner, both arising from protuberance. Terminal (5th) segment armed with 9 setae/aesthetasc: 4 setae articulated at base on ventral side, 1 aesthetasc and 2 setae sharing common base, situated on terminal process, 1 terminolateral seta arising from protuberance and 1 subterminal dorsal seta stippled with traces of hairs.

\section{Copepodid II}

First antenna (fig. 5) 6-segmented $(87 \times 31 \mu \mathrm{m})$. Segment 2 elongate. Segment 3 split off distally by 2nd segment of $\mathrm{CI}$. This is concluded from the now distal position of the proximal aesthetasc and the unchanged peculiar setae of the distal segments.

Segment 1 has proximal field of fine hairs on dorsal side. The simple seta is stippled with traces of spinules. On 2nd segment a double-furrowed area visible midlength. Setation has increased from 4 in C I to 6 setae/aesthetasc. Proximal aesthetasc confluent at base with accompanying seta. The new $3 \mathrm{rd}$ segment bears strong seta arising from protuberance on dorsal side. Segment 4 has developed additional seta situated on protuberance on dorsal side. Segment 5 bears additional seta proximally on dorsal side. On terminal 6th segment, one of the setae which were confluent with terminal aesthetasc in $\mathrm{C}$ I, is reduced to short remnant (not counted).

\section{Copepodid III}

First antenna (fig. 5) is 7-segmented (106 $\times 32 \mu \mathrm{m})$. Segment 2 even more elongate than in preceding 


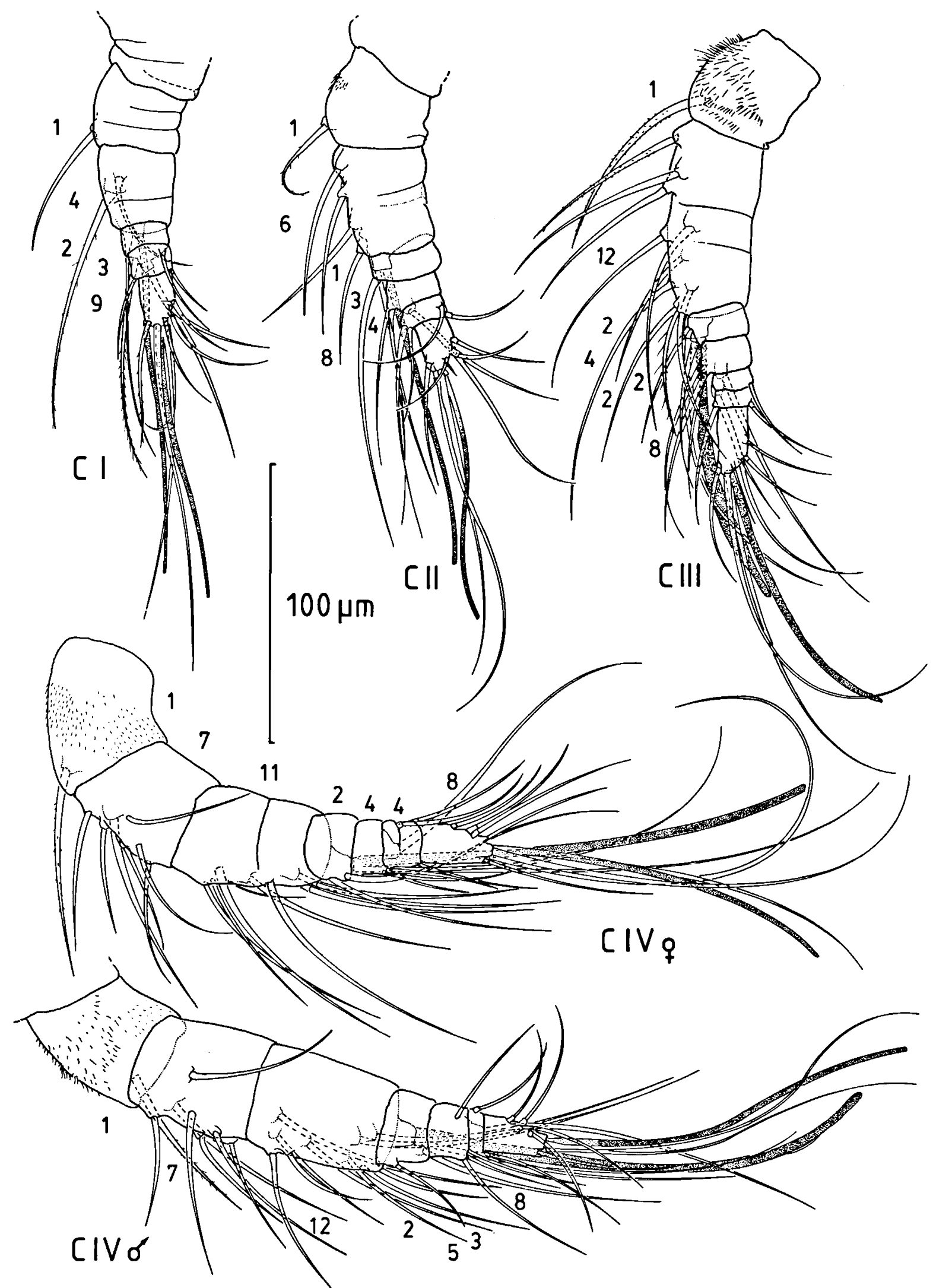


stage. Segment 6 is new and is a product of division of 5th segment of C II. This is revealed by the setation patterns of the new segment and the surrounding ones.

Segment 1 coated on lateral and dorsal side with fur of hairy spinules which become longer dorsally. Segment 2 with increased number of setae, 6 more than in C II on dorsal side and deep furrow proximally on ventrolateral half of segment only and another slight furrow midlength on segment. Proximal seta stippled with traces of spinules and the seta at dorsodistal corner with well developed but scarce spinules on both sides. Segment 3 bears additional seta proximally on dorsal side. Segment 5 has 4 setae on the dorsal and dorsolateral sides. The new 5th and 6th segments each bear 1 strong seta dorsally and 1 articulated seta on distal corner ventrally. These setae are held to be homologous with the 4 setae on 5th segment of C II.

\section{Copepodid IV}

First antenna (fig. 5) 7-segmented in both sexes as in previous stage. Sexual dimorphism apparent in setation and in segment structure.

First antenna of male $(150 \times 39 \mu \mathrm{m})$. Segment 2 is new. This is decuced from the segment number and the setation of the segments, proximal to the seta/aesthetasc complex. Distal part of first antenna has reduced segment number. It appears that 5 th and 6th segments of C III are fused and represent 6th segment in male $C$ IV. This new segment has reduced 1 of the 4 setae of the 2 segments in C III; it bears 7 and the 3rd segment bears 12 setae/aesthetasc, an increase of 7 setae compared with the homologous 2nd segment of C III. Segment 5 has either developed 1 new seta on ventrolateral side or taken it over from the fused 6th segment which lacks 1 seta as mentioned above.

First antenna of female $(154 \times 38 \mu \mathrm{m})$. Segment 2 new as in male. A well developed ventrolateral furrow is seen in distal third. It is suggested that the 6th segment is formed by fusion of the 5th and 6th segments of C III as in male. A ventrolateral suture line is still present on the outer side. Setation is different from that in male on 3rd segment, bearing only 11 setae. Seta number of whole distal part identical with that of C III, provided it is accepted that segments 5 and 6 have fused.

\section{Copepodid V}

First antennae (fig. 6) 6-segmented in male and 8 -segmented in female.

First antenna of male $(146 \times 39 \mu \mathrm{m})$ transformed by swelling of segments, fusion and shortening of distal part, and by formation of terminal outgrowth in dorsal corner which becomes pointed process in adult male. It is suggested that the 4th segment of male C IV has become larger and developed 3 new dorsal setae whereas segments 5 and 6 have fused to form the 5th segment of $\mathrm{C} \mathrm{V}$.

First antenna of female $(185 \times 38 \mu \mathrm{m})$ has developed new 3rd segment. Its border line is situated where there had been the furrow of 2nd segment of female C IV. All segments elongate. Segment 2 has increased number of setae from 7 to 12 . New 3rd segment and 4th together have 5 additional setae.

\section{Copepodid VI}

First antennae (fig. 6) about 7-segmented in male and 8-segmented in female.

First antenna of male $(193 \times 35 \mu \mathrm{m})$ with new 3rd segment. This segment split off proximally from the 3rd segment of $\mathrm{CV}$ which is obvious from setation patterns. Distal part (i.e. segments 4-6 of male $C \mathrm{~V})$ fused to a degree that even segment identification is difficult. Terminal segment has developed distal outgrowth facilitating clasping dorsolateral margin of female cephalothorax. Segment 2 bears 12 setae as in male $C V$. On new 3rd segment a single aesthetasc is developed proximal to setae/aesthetasc complex of 4th segment. On 6th segment several lamellae have appeared on dorsal side. These structures are likely to enhance tight contact with female cephalothorax. Terminal segment bears at least 15 setae/aesthetasc including aesthetasc with 3 surrounding setae and articulated setae of C V. It is therefore concluded that terminal segment of adult male is result of fusion of the 5th

Fig. S. Alteutha interrupta. Development of first antennae of copepodids I-IV. 


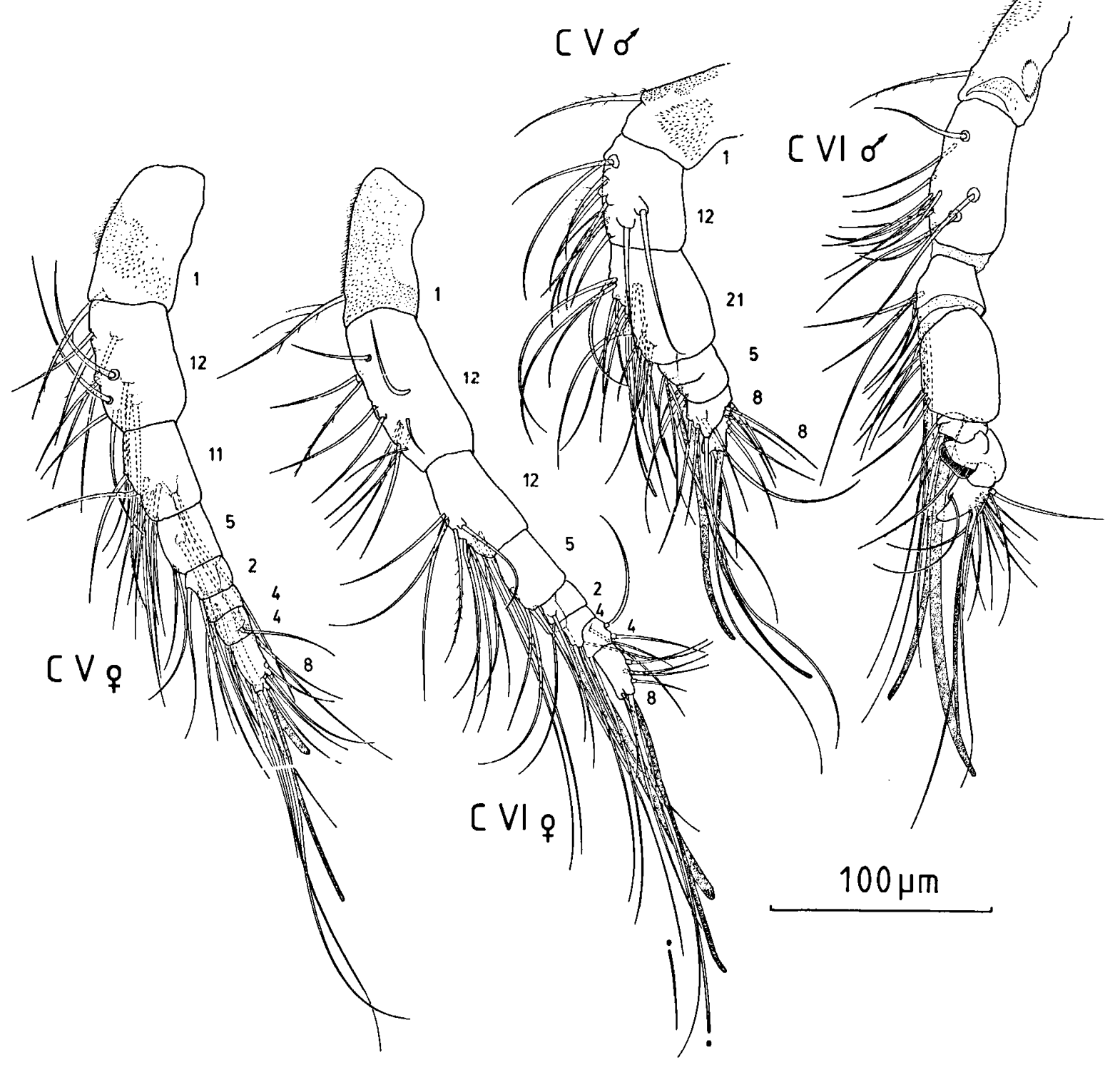

Fig. 6. Alteutha interrupta. Development of first antennae of copepodids V and VI.

and 6th segments of $\mathrm{C} \mathrm{V}$. If 7 segments are counted, 1 new segment must have developed between 4 th segment bearing the setae/aesthetasc complex, and terminal segment. The new segment border may coincide with the midlength furrow of 4 th segment of C V.

First antenna of female $(217 \times 29 \mu \mathrm{m})$ does not deviate markedly from that of female C V. Segment 2 elongate and segment 3 bears additional dorsal seta.

\section{Macrosetella gracilis (MIRACIDAE)}

The first antennae are drawn from outer side. The segments (except the first in C III and the adult male) are devoid of any ornamentation. The segments are characterized by an increasing length/ width ratio during the copepodite development. All setae are short and usually without spinules. 


\section{Copepodid I}

First antenna (figs. 7, 14) 5-segmented $(130 \times 20$ $\mu \mathrm{m})$. Segment 2 as long as 3 . Segment 1 bears 1 seta with only traces of a few spinules in dorsodistal corner. Segment 2 bears 2 dorsal setae and a single subdistal dorsolateral aesthetasc. One of the setae originating in distal third and the other formed on outer distal corner. Segment 3 bears 1 dorsal seta in distalmost corner and 1 shorter seta midlength. Segment 4 bears 1 dorsal seta in distalmost corner. Segment 5 bears 5 setae, a terminal aesthetasc on ventral corner, and a dorsal spinous process which is divided halfway. The 2 setae between aesthetasc and spinulose process are confluent at base. One of the proximal setae originates in proximal third, the other 2 midlength on ventral side of distal segment.

\section{Copepodid II}

First antenna (fig. 7) 6-segmented (183 $\times 23 \mu \mathrm{m})$. The new segment is the 3rd one which split off distally from 2 nd segment of C I. Segment 2 has become elongate; it has an additional seta dorsally on proximal fourth and aesthetasc now is accompanied by seta with which it shares a common base in dorsodistal corner. New 3rd segment bears 1 seta in dorsodistal corner. Segment 4 bears 1 seta midlength, 1 seta at three-fourth and 1 seta on dorsodistal corner. Segment 5 bears 2 setae, one subdistally and one distally on dorsal corner. The 2 setae midlength of segment 6 have become distinctly articulated at base and terminal spinous process has lost its division.

\section{Copepodid III}

First antenna (fig. 7) 6-segmented as in C II $(256 \times 26 \mu \mathrm{m})$. Segment 2 even more elongate and nearly as long as 3 subsequent ones together. Double line of furrows present in proximal third and another one midlength. Seta of 1st segment completely reduced, and replaced by short row of short spinules. There is an increase in number of setae on dorsal side of 2 nd segment from 5 in C II to 11 . Segment 3 has additional seta midlength on dorsal side. Terminal aesthetasc on segment 6 now joins common base of two terminal setae.

\section{Copepodid IV}

First antenna (fig. 7) 7-segmented (273 $\times 28 \mu \mathrm{m})$. From position of proximal aesthetasc it is concluded that 2 nd segment is new and split off proximally by segment 2 of C III (division taking place in area of previous double line of furrows). Segment 1 has lost spinule row. Segment 2 bears 6 dorsal setae; segment 3, 11 setae/aesthetasc. Distal 4 segments do not show marked changes except in size and in that proximal seta of distal segment is articulated.

\section{Copepodid V}

First antenna (fig. 8) 7-segmented as in C IV in both sexes. Sexual dimorphism shown by segment length and setation patterns.

First antenna of male $(341 \times 31 \mu \mathrm{m})$. Segment proportions of C IV retained. Segment 2 bears 8 setae on dorsal side. Segment 3 bears 16 setae/aesthetasc. On 4th segment there is now additional tiny setule between preexisting setae. Segment 5 has additional seta on proximal third of dorsal side and distal segment shows terminal knob (process-like outgrowth). In contrast to female, dorsalmost of 2 terminal setae reduced in size and half as long as accompanying one.

First antenna of female $(400 \times 27 \mu \mathrm{m})$. Segment 3 elongate with furrow in distal half. Fourth to 6 th segments elongate but with same proportions as in C IV, whereas distal segment retains more or less same structure and proportions as in C II to C VI (except adult male).

Segment 2 bears 6 setae on dorsal side; segment 3,5 setae proximally of furrow and 6 setae/aesthetasc distally of it. Setation remains almost unchanged on 4th to 7 th segment.

\section{Copepodid VI}

First antenna (figs. 7, 8) with increased dimorphism.

First antenna of male (fig. 7) (ca. $406 \times 29 \mu \mathrm{m}$ ) 9-segmented. New are 3rd and 5th segment. Segment 3 split off proximally by 3rd segment of $\mathrm{C} \mathrm{V}$. This is concluded from setation patterns of 2 nd segment and position of the proximal aesthetasc. It is difficult to decide whether 5th segment derives from 3rd or from 4th segment of male C V. Segment 2 bears 8 setae dorsally in distal half. Segment 

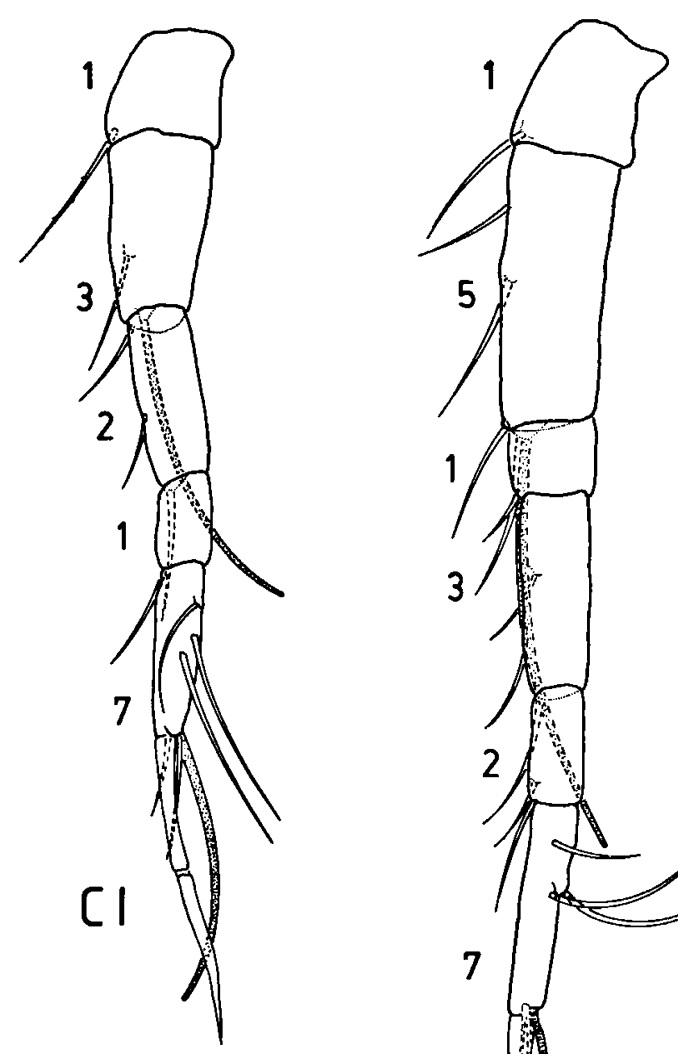

0
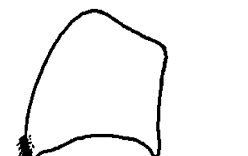


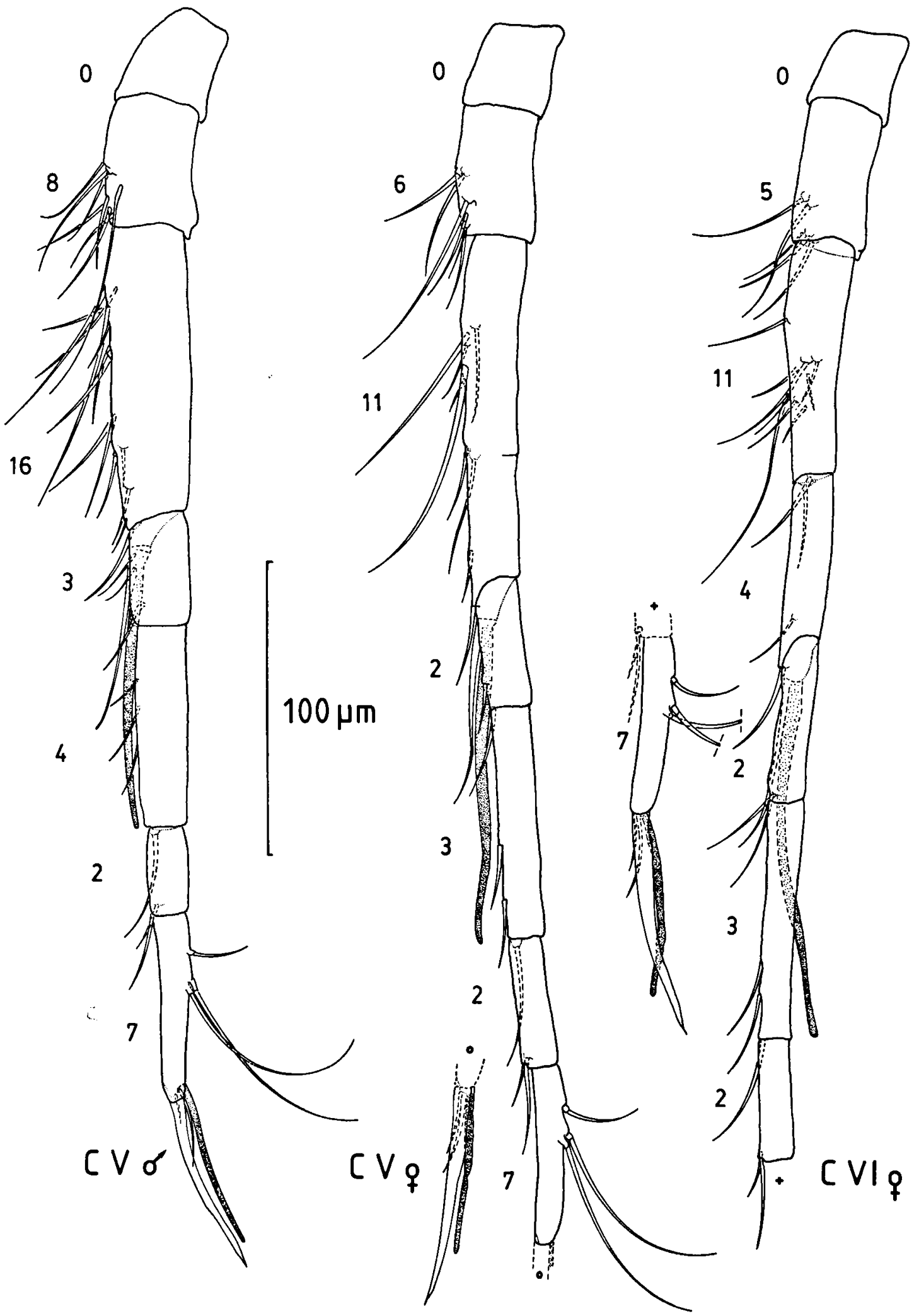

Fig. 8. Macrosetella gracilis. Development of first antennae of copepodid V and female VI. 
3 bears bundle of setae on dorsalmost corner. Segment 4 bears 1 long seta midlength and 3 short blade-like setae dorsally in distal half. Group of setules situated near base and on dorsal side of aesthetasc/seta complex. Short 5th segment bare of setae. Segment 6 bears 1 longer blade-like seta on outer side and 2 rows of proximal scales as well as 1 setule on dorsodistal corner lateral to geniculating point between 6 th and 7 th segment. Segment 7 only bears 2 dentiform processes subdistally and 1 small seta on dorsodistal corner. The 2 setae dorsodistal of 8th segment greatly reduced in size. Terminal 9th segment considerably transformed: proximal 3 articulated setae persist whereas terminal ones fuse with distal part of segment; tube-like structure originating midlength on outer side is interpreted as former terminal aesthetasc of $\mathrm{C} \mathrm{V}$, even though it is granular only in distal third. At tip the segment bifurcates twice: first giving off what had been the spinulose process from C I onwards (this is judged from the characteristic very fine tapering tip), and then splitting into 2 slender seta-like outgrowths (probably aforementioned couple of terminal setae), tips of all 4 structures contain luminous granules. According to Björnberg (1965) the male clasps the furcal setae of the female.

First antenna of female (fig. 8) $(488 \times 25 \mu \mathrm{m})$ 8-segmented. Segment 3 is new and is formed by proximal division of 3rd segment of $\mathrm{C} \mathrm{V}$. On 2 nd segment one of the setae has been reduced. Total setae/aesthetasc number of 3rd segment of $\mathrm{C} \mathrm{V}$ and homologous 3rd of C VI has increased from 11 in C V to 15 in C VI. Distal segments $(5-8)$ remain practically unchanged, except for size.

\section{Thalestris longimana (THALESTRIDAE)}

The first antennae are drawn in outer view (except adult male which is drawn in inner view, fig. 10). The drawings are made with the dorsal side pointing left or to the top of the page. The segments (except the 1st of C II-C VI) are devoid of any ornamentation. The setae usually lack spinules.

\section{Copepodid I}

First antenna (figs. 9, 13) 6-segmented $(78 \times 31$ $\mu \mathrm{m})$. Segment 1 broader than segment 2 , but equal- ly long. Segment 2 is four-fifth as long as distal 4 segments together. Segment 1 bears 1 plain seta on protuberance in dorsodistal corner. Segment 2 with 3 setae in dorsodistal half and 1 subdistal aesthetasc, originating from protuberance and setalike at base. Segment 3 bears 2 setae: one on dorsal outgrowth which has a slight notch proximally, second on dorsolateral outgrowth with basal subdivision. Segment 4 bears 1 articulated seta distally on ventrolateral side. Two setae present on 5th segment: stronger dorsal one situated on distal corner, and an articulated one originates from ventrodistal corner. Terminal 6th segment bears all 10 setae on distal half: 4 articulated setae on ventral side, terminal "trithec" consisting of 1 aesthetasc and 2 accompanying setae of equal length, 1 subdistal seta with protuberance as base, 1 slender seta originating at base of setae/aesthetasc complex and 1 shortcut seta between the articulated setae. These last two will be reduced in the next stage.

\section{Copepodid II}

First antenna (fig. 9) 7-segmented (101 $\times 32 \mu \mathrm{m})$. Segment 3 is new and has been split off by segment 2. This is concluded from the now distal position of proximal aesthetasc and from the particular setae of 4th segment which indicate homology with 3rd segment of C I. Segment 2 has become elongate.

Segment 1 bears proximal row of fine spinules, segment 2, 2 additional new setae; third seta on proximal margin originates from protuberance. Aesthetasc situated on dorsolateral process and accompanied by long seta. Another seta nearly as long as former, situated on knob-like process at base of setae/aesthetasc process on dorsal side. Newly formed 3rd segment bears strong seta originating from basal protuberance on dorsal side. Segment 4 has an additional seta between the preexisting two. Segment 5 bears an additional strong seta dorsolaterally. The already mentioned reduction of the 2 small setae takes place on the 7 th segment.

\section{Copepodid III}

First antenna (fig. 9) 7-segmented as in preceding stage $(132 \times 46 \mu \mathrm{m})$. Segment 2 even more elongate, 


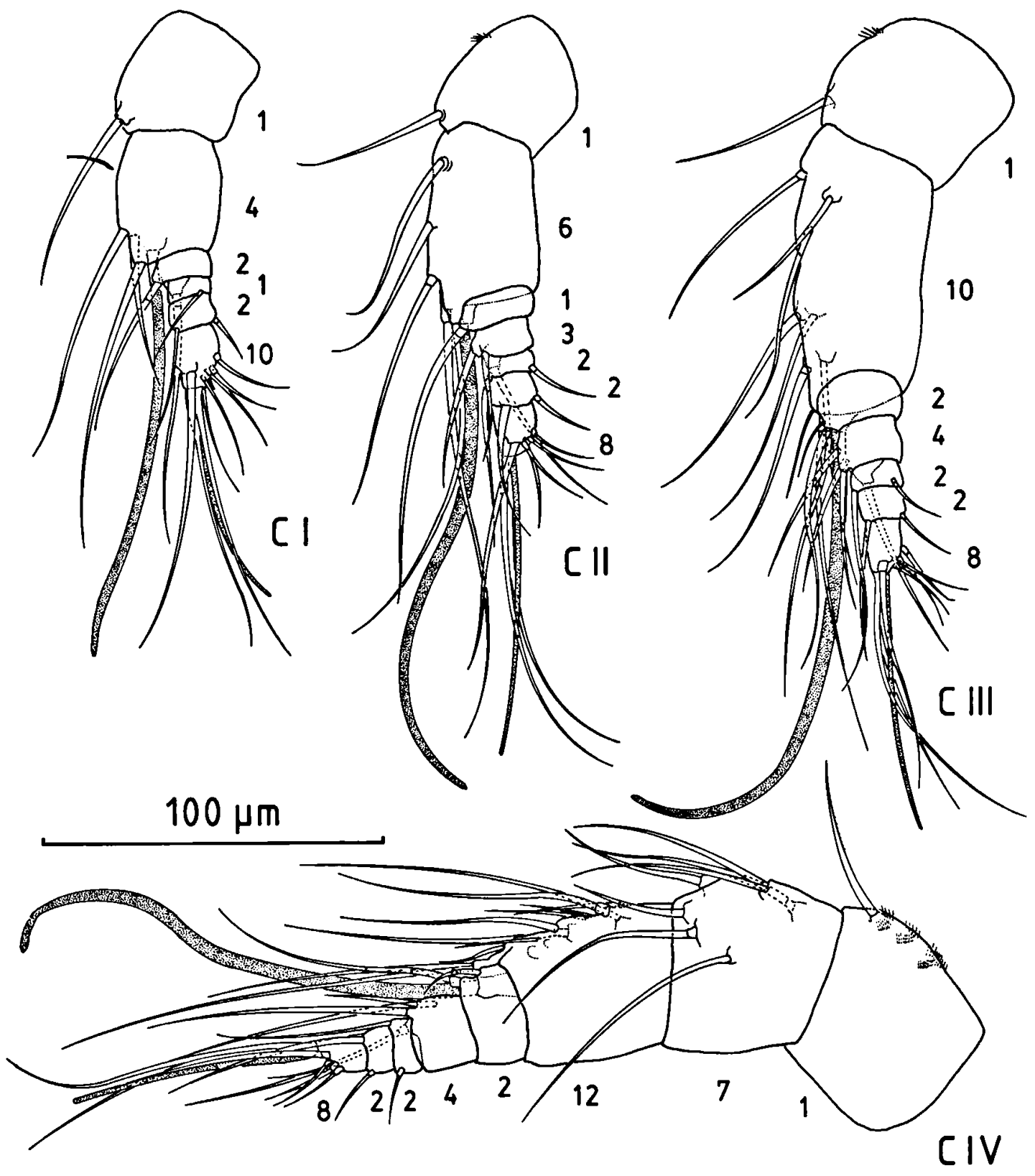

Fig. 9. Thalestris longimana. Development of first antennae of copepodids I-IV.

with additional 4 setae on dorsal side; one of the proximal setae and the seta accompanying the aesthetasc originating from a protuberance. Segment 3 bears an additional small seta on proximal outgrowth. Segment 4 bears another seta midlength on dorsal side. Distal 4 segments not changed markedly, except slightly in size.

\section{Copepodid IV}

First antenna (fig. 9) 8-segmented (156 $\times 54 \mu \mathrm{m})$. Segment 2 is new and split off proximally from 2 nd segment of C III. This is judged from position of proximal seta/aesthetasc complex and from reduced length of former 2 nd segment. On 1st segment 3 rows of spinules. New 2 nd segment bears 7 


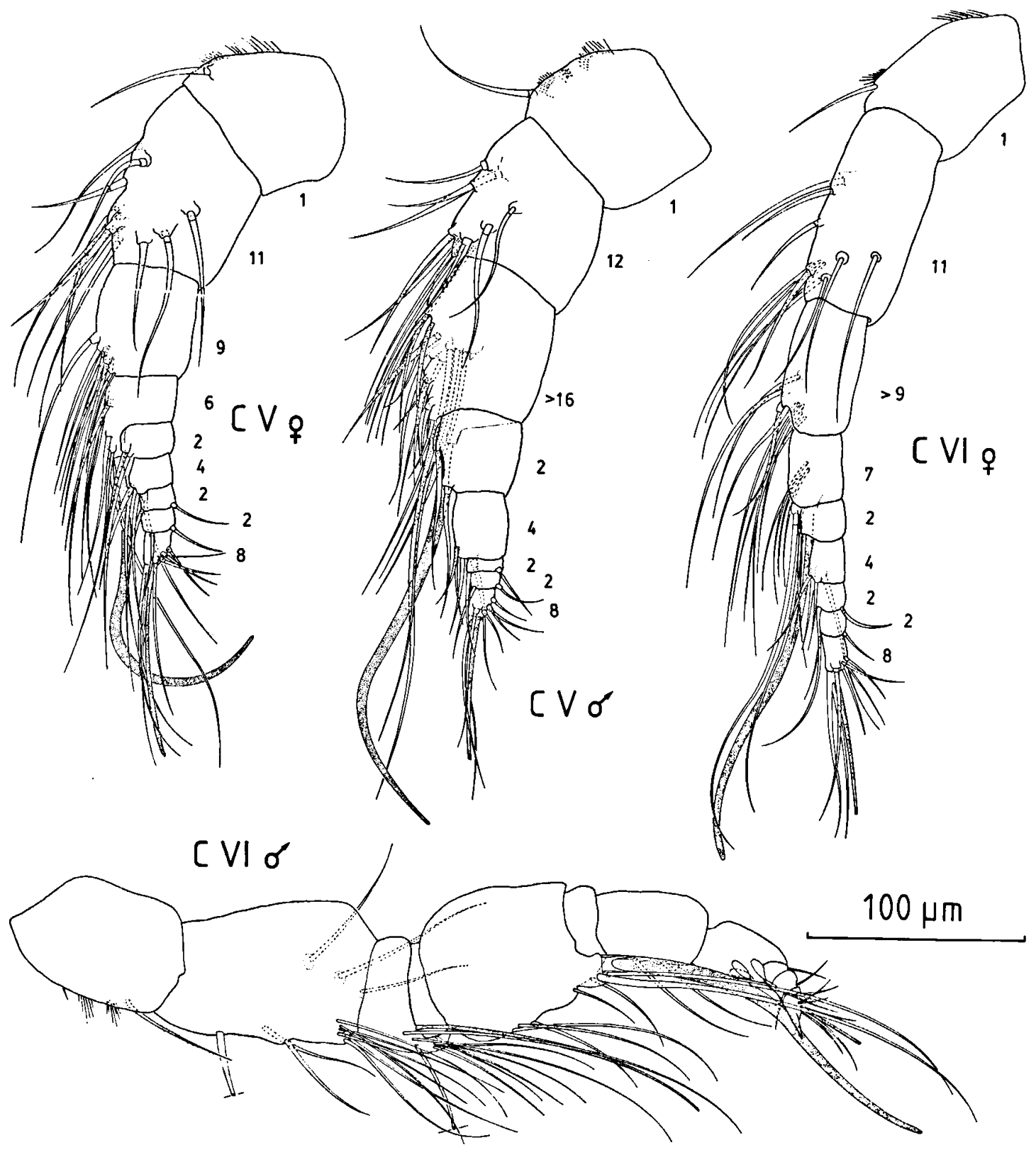

Fig. 10. Thalestris longimana. Development of first antennae of copepodids V and VI.

setae. On dorsolateral side a characteristic group of 3 setae, all arising from small cuticular hump; distal one shortest, proximal one longest. These 3 setae persist to adult stage of both sexes. Segment 3 bears 12 setae/aesthetasc, most of them arise from cuticular protuberances. Five distal segments not changed, except in size.

\section{Copepodid V}

First antenna (fig. 10) 8-segmented in male and 9segmented in female. Seta/aesthetasc complex situated dorsodistally on 3rd segment in male and 4th segment in female. Setation patterns of proximal part of first antennae and segment sizes differ as well in both sexes. Ventralmost 2 setae of the setae-triplet on the 2 nd segment articulated in both sexes. 
First antenna of male $(204 \times 81 \mu \mathrm{m})$ has retained segment number of C IV. Segments 4 and 5 relatively increased in size. Segment 2 bears 5 new setae and segment 3 more than 16 setae/aesthetasc; distal 5 segments not changed markedly as regards setation patterns.

First antenna of female $(205 \times 61 \mu \mathrm{m})$ has new segment, the 3rd, which has budded off proximally from 3rd segment of C IV. This is concluded from position of seta/aesthetasc complex and characteristic triplet of setae on 2nd segment mentioned earlier. Segment 2 has 4 new setae on dorsal side. New 3rd and 4th segment together have 15 setae (instead of 12 on 3 rd segment of C IV). On distal 5 segments setation not changed.

\section{Copepodid VI}

First antenna (fig. 10) of adult male 10-segmented, of female 9-segmented as in previous stage.

First antenna of male $(307 \times 65 \mu \mathrm{m})$ with new 3rd segment split off proximally from 3rd segment of male C V. This is concluded from more or less unchanged 2nd segment and the distal position of the setae which correspond to the most proximal group of setae on the 3rd segment of C V. In distal part a new 5th segment is formed. It is suggested that this segment derives from 3rd segment of $\mathrm{C} \mathrm{V}$ because of its wider diameter.

Segment 2 broadens in distal third. New 3rd segment bears newly developed single aesthetasc and 4th segment which has now swollen appearance, bears seta/aesthetasc complex of 3rd segment of $C$ $\mathrm{V}$. Setae on dorsal side of 6 th segment are suggested to be homologous with those of 4th segment of $C$ V. On 7th segment 1 dorsodistal articulated seta, 3 scales and other cuticular formations proximal to these. It is suggested that these structures correspond to 4 setae of 5th segment of male C V. Next 3 distal segments still have setation pattners of corresponding segments of $\mathrm{C} \mathrm{V}$, except 8th segment where only 1 ventral seta is visible. Segment 10 drawn out into pointed outgrowth facilitating clasping of female's dorsolateral margin of cephalothorax. Geniculation between 6 th and 7 th segment.

First antenna of female $(257 \times 43 \mu \mathrm{m})$ has more slender and longer segments. Segment 2 relatively longer than others. Seta-number increased on 3rd segment to at least 9 setae; 4th segment bears 1 additional seta (i.e., 7) on dorsal side. Setation patterns on distal 5 segments not changed.

\section{Heterolaophonte minuta (LAOPHONTIDAE)}

The left first antennae are drawn in dorsal view (except adult male which is shown in ventral view fig. 12). Except for the 1st segment all segments are devoid of ornamentation. The outer margin of the first antennae points to the top (except in adult male where it points to the bottom of the page). The setae lack spinules, except for second seta on 1st segment of C I and some setae on 5th segment of adult male.

\section{Copepodid I}

First antenna (figs. 11,14$) 3$-segmented $(32 \times 14$ $\mu \mathrm{m})$. First 2 segments of equal length, terminal one slightly longer. Segment 1 bears proximal spinule row, 1 bare and 1 peculiar seta on outer distal corner; this seta is club-like and ends in long hair; it bears spinules along outer side, and 1 spinule subterminally on inner side. Segment 2 bears 1 seta at midlength, 1 seta of similar length arising from knob-like process in outer distal corner and 1 much smaller seta in between. Single proximal aesthetasc situated subdistally on protuberance on ventrolateral side; it is seta-like in the basal fourth. Segment 3 bears 3 setae on outer and 5 articulated setae on inner margin, the proximal of these is distinctly separated from distal $4 ; 1$ subterminal short seta on inner side, terminal aesthetasc has common base with 2 other terminal setae and 1 articulated seta originates subterminally. The latter will be reduced in next stage. The 14th seta is developed on protuberance dorsad of the group of 4 articulated setae.

\section{Copepodid II}

First antenna (fig. 11) 4-segmented (46×14 $\mu \mathrm{m})$. Segment 3 is new and split off distally by 2 nd segment of C II. This is judged from position of proximal seta/aesthetasc complex and relatively unchanged terminal segment.

The peculiar seta on outer distal corner of C I 


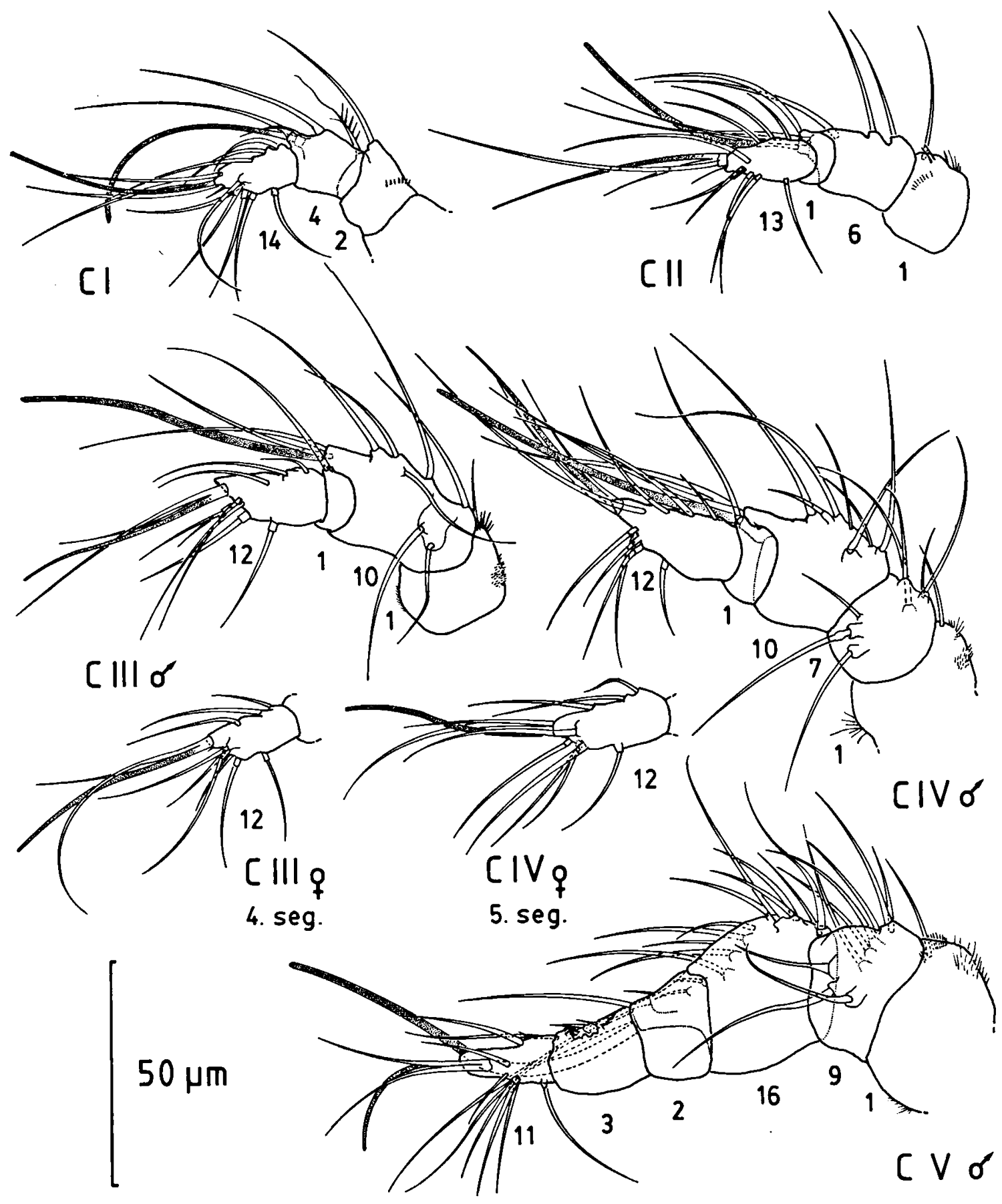

Fig. 11. Heterolaophonte minuta. Development of first antennae of copepodids I-V.

reduced; there is a second row of spinules on 1st segment. Segment 2 has 2 more setae on outer side. Proximal aesthetasc has common base with seta on ventrolateral process. Additional seta originates ventrally at base of this process. Aforementioned articulated seta on 4 th segment totally reduced so that seta/aesthetasc number on terminal segment is 13. 


\section{Copepodid III}

First antennae (fig. 11) 4-segmented in both sexes as in previous stage. Sexual dimorphism expressed by terminal outgrowing tip of male. Segment 2 is elongate and broadest distally.

First antenna of male $(57 \times 20 \mu \mathrm{m})$. Spinules around seta on outer distal corner of 1st segment longer, and field of fine hairs appears on inner side. Segment 2 has developed proximal cuticular saddlelike structure on dorsal side with 2 setae. Setation increased from 6 setae/aesthetasc in C II to 10 in C III. On 4th segment small hairlike seta on inner terminal margin reduced.

First antenna of female $(51 \times 16 \mu \mathrm{m})$ as in male but without above-mentioned terminal tip.

\section{Copepodid IV}

First antennae (fig. 11) 5-segmented. Segment 2 is new and split off proximally by 2 nd segment of $C$ III. This is judged from former 2 nd segment becoming reduced in length and similar appearance of remaining segments. Sexual dimorphism as in preceding stage.

First antenna of male $(83 \times 25 \mu \mathrm{m})$. New 2 nd segment bears 7 setae. It is suggested that 2 setae of saddle-like structure of C III are the 2 innermost of the group of 3 dorsal setae. Both these setae originate from hump-like structures, 3rd seta appears dorsally; other 4 setae situated on outer margin. Other segments not changed in seta number. Small setule on outer margin of 4 th segment not counted as seta.

First antenna of female $(70 \times 24 \mu \mathrm{m})$ as in male, without above-mentioned terminal tip.

\section{Copepodid V.}

First antennae (figs. 11, 12) of male with 6 segments and of female with 5 segments. Segment structure and setation of all segments, except 1 st, sexually dimorphic as well.

First antenna of male (fig. 11) $(113 \times 30 \mu \mathrm{m})$ with new segment, the 5th which is budded off proximally from terminal segment. This is concluded from setation pattern of terminal segment of C IV. The distalmost of 3 outer setae longer than distal segment and situated in outer distal corner of 5th segment of male $\mathrm{C} \mathrm{V}$, whereas proximal ones are situ- ated midlength and are much reduced in size. Thus terminal 6th segment of male C V has 11 setae/aesthetasc.

Seta number on 2nd segment is 9 and on 3rd segment 16. Small setule on 4th segment of C IV has become a second seta. Besides earlier mentioned distal seta, outer margin of 5th segment characterized by 2 scale-like setae and some cuticular ridges. Segment 6 has 11 setae/aesthetasc.

First antenna of female (fig. 12) $(101 \times 27 \mu \mathrm{m})$ with elongate segments, but same number as in $C$ IV. Furrows on distal part of 3rd and on proximal part of 5th segment indicate where new segments will appear in next stage. The only change in setation as compared with C IV takes place on 2 nd segment: an additional seta is developed on outer margin.

\section{Copepodid VI}

First antennae (fig. 12) of male of 8 segments and those of female of 7 segments.

First antenna of male $(110 \times 28 \mu \mathrm{m})$ drastically transformed to a complex subchirocer antennule, with a 5th segment almost swollen to circular shape, enabling male to clasp tips of female's $P$ 4. Two indistinctly visible segments are new: 3 rd and 4th segment. Both must have been split off proximally by 3rd segment of male $\mathrm{C} \mathrm{V}$ because of position of seta/aesthetasc complex and peculiar setae-triplet of 2 nd segment. It is suggested that 5 th segment of $\mathrm{C} V$ has been transformed to a shape represented by 7th segment of adult male which still bears distal seta on outer corner.

Segment 2 bears 9 setae as in homologous segment of C V. Swollen 5th segment characterized by dorsolateral field with cuticular formations and 2 particular setae, which are straight in proximal twothirds and curved, blade-like distally. These setae armed with double-row of spinules on outer margin. Ventralmost bears 2 bifurcating spinules terminally, and other seta tapering without bifurcation. Segment 6 bears at least 2 scales on concave margin and several curved cuticular ridges. Segment 7 bears the already mentioned seta and terminal 8 th segment bears 10 setae/aesthetasc.

First antenna of female $(118 \times 28 \mu \mathrm{m})$ has developed 2 new segments with borderline along the furrows of previous stage. New 3rd segment split off 


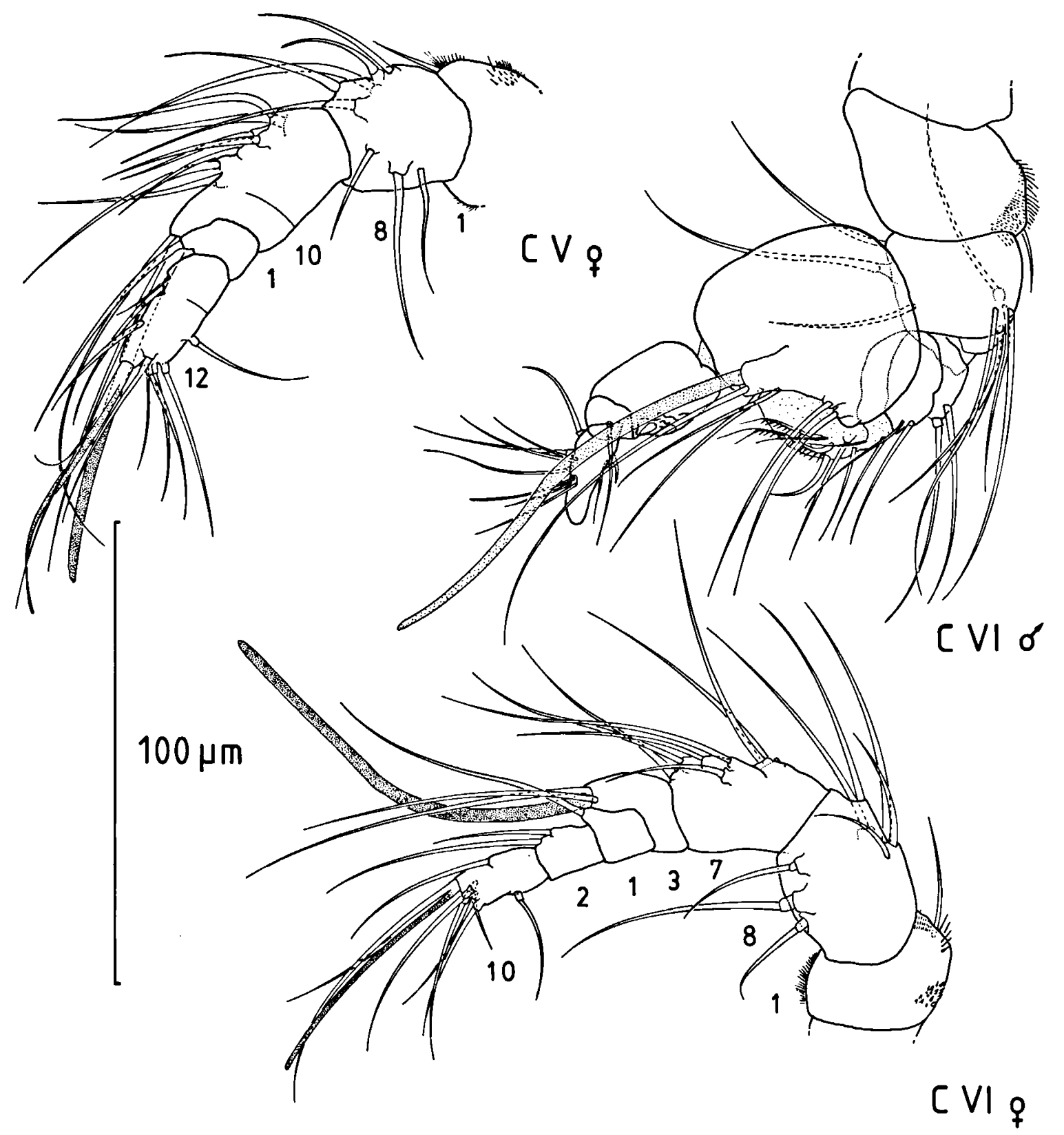

Fig. 12. Heterolaophonte minuta. Development of first antennae of copepodids V and VI.

proximally by 3 rd segment of female $\mathrm{C} \mathrm{V}$, and new 6th segment derives from proximal part of terminal 5th segment of $C V$. There is no new seta. The 7 setae of 3 rd segment plus 3 setae of the 4 th correspond to 10 setae of 3 rd segment of $\mathrm{C} \mathrm{V}$. The 2 setae of 6th segment plus 10 of terminal segment correspond to setae of 5 th segment of female $\mathrm{C} \mathrm{V}$.

\section{Discussion}

\section{Resolution problems}

It is often difficult to decide whether a segment is already divided or whether only a furrow has been formed. In rare cases a division seems to be present 
only on one side of the antennule (e.g. Tisbe gracilis C II-C V, the 2 subterminal segments - fig. 14 and Dahms \& Bergmans, in press; Drescheriella glacialis female C V - fig. 14 and Dahms, 1987a). In cases of fusion, it is difficult to determine the segment number if a suture-line is still present. It is particularly difficult to make exact statements on segment number and structure of adult male antennules (figs. 2, 6, 7, 10, 12). Therefore segment armature of adult males is not described in this study except for Tegastes clausi (fig. 13), Macrosetella gracilis and Drescheriella glacialis (fig. 14) where clear statements can be made.

Sexual dimorphism often makes its first appearance with only slight morphological changes (e.g. Tegastes clausi - fig. 3; Heterolaophonte minuta fig. 11). Therefore information from the literature should be considered with caution.

In case of Ectinosoma melaniceps (figs. 1, 2, 13; tab. I) the distal antennule segment is regarded as subdivided because of the process-like appearance of the terminal part. In the adult stage the proximal border line of the process has disappeared and the distal segment has a structure similar to that of other Harpacticoida.

\section{General development of first antennae}

It has been noted by several authors that antennule formation is not achieved merely by addition of segments and not only through successive enlargements and subdivisions of certain segments, but also fusions of segments take place. Fusion and proliferation of new segments are processes that may occur simultaneously from one stage to the next.

As has been pointed out by Dahms (1988) the origin of newly formed segments can be determined by comparison of the setule numbers of segments, by relative segment length, by furrows indicating previous partition lines and by the position of the segment which bears the proximal aesthetasc. This particular segment is characterized by the aesthetasc/seta complex of later stages (usually $\mathrm{C}$ II-C VI) where both have a common base, by its position as 2nd segment of C I and C II (except in Scutellidium arthuri and Porcellidiidae) and by its potential to give off new segments both distally and proximally. It can therefore be homologized with ease and certainty during the copepodite phase. In Polyartha sensu Lang, and at least in adults of Cervinia the equivalent (possibly homologous) segment has 2 aesthetascs without accompanying setae at least from $\mathrm{C} \mathrm{V}$ onwards. Its position in the sequence of antennular segments allows to decide whether new segments have been formed distally or proximally and whether fusion has occurred or not.

In at least some species of Clytemnestridae, Peltidiidae, Tegastidae, Tachidiidae, Harpacticidae, Diosaccidae and Thalestridae more than one proximal aesthetasc (besides the terminal one) are found in adult males. At least in Tegastes clausi (fig. 4), Alteutha interrupta (fig. 6) and Thalestris longimana (fig. 10) 2 proximal aesthetascs are present in adult males. One of these aesthetascs is derived from a single seta lying proximad to the aesthetasc/seta complex on the 3rd segment of male $\mathrm{C} \mathrm{V}$ first antenna. In adult males each of these aesthetascs originates from different segments (Dahms, 1988). There is another distal aesthetasc originating from the naupliar terminal segment and arising together with 2 setae from a common base. This "tritheka" appears to be quite common among Harpacticoida throughout the copepodite phase though often it is difficult to see.

In Longipedia americana (Onbé, 1984) even 2 terminal aesthetascs are present from C I onwards.

The first antennae of adults always have longer and much more slender segments than copepodids. Also, almost only in adults is the chitin of the segments thicker so that it appears as a double margin. These two peculiarities may be due to the mechanical necessity to leave room inside each larval exoskeleton for growth of the exoskeleton of the subsequent stage.

In later copepodite stages there are 2 zones of segment formation in the middle part of the antennule. The proximal zone is identical with the aesthetascbearing segment of C I/C II which splits off at least 1 segment in all Harpacticoida. The second zone corresponds with one of the subterminal segments or with the proximal part of the terminal segment.

The aesthetasc-bearing second segment splits off at least 1 segment distally from C I to C II (exceptions: Polyarthra; in Scutellidium arthuri and Por- 

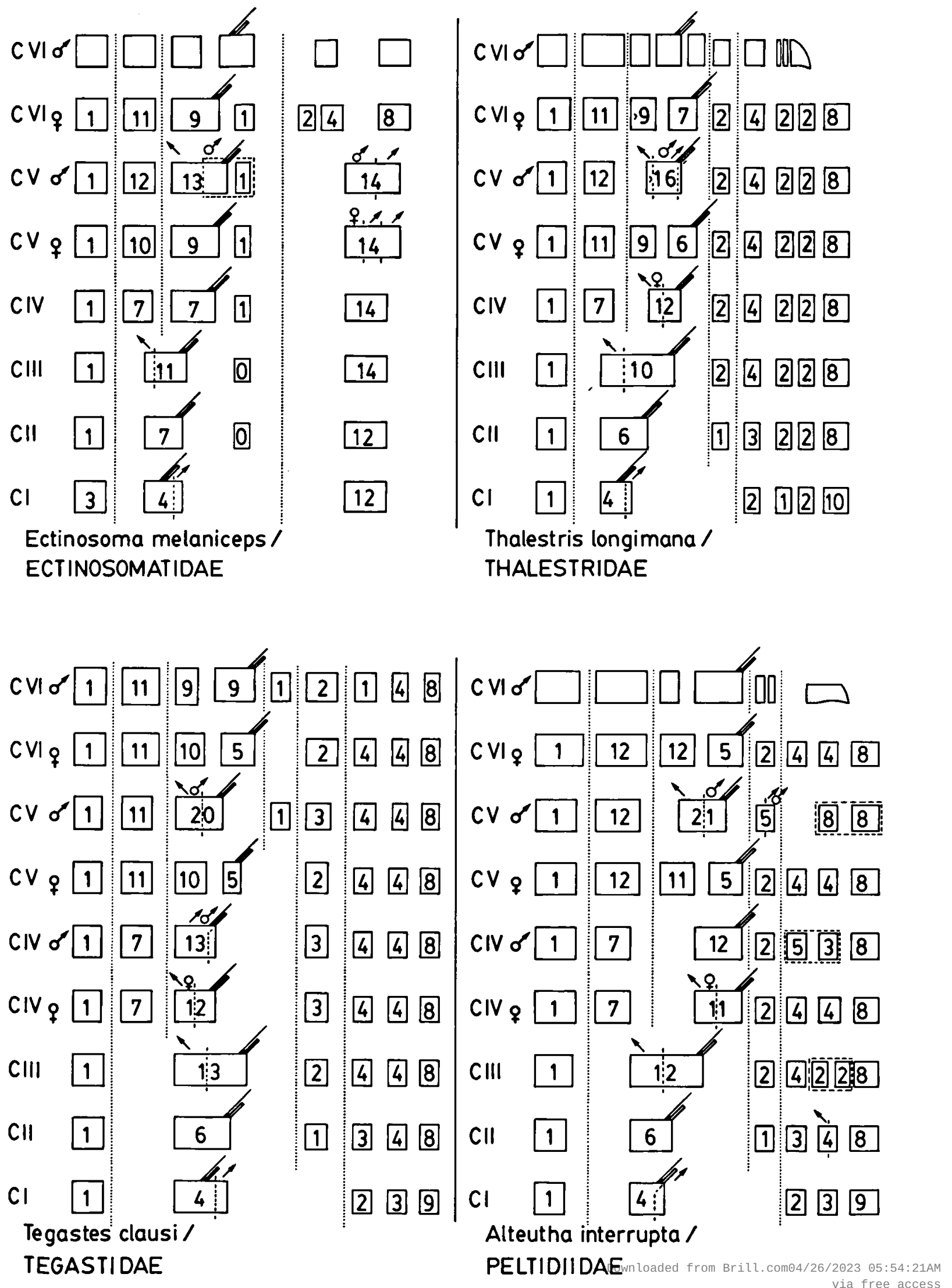
cellidium sarsi 1 segment is split off proximally). In Tisbe spp. and Diarthrodes cystoecus 2 segments and in females of Canthocamptidae and Sacodiscus ovalis 3 segments are developed distally.

In $C$ II and C III segment number remains the same (exceptions: Euterpina acutifrons, Tisbintra jonesi, Scutellidium arthuri, Alteutha interrupta, Diarthrodes cystoecus, Nitocra spinipes) although the number of setae increases and segment size is different.

The aesthetasc-bearing segment of C III splits off at least 1 segment proximally which appears in C IV (exceptions: Tisbintra jonesi, Scutellidium arthuri, Diarthrodes cystoecus, Nitocra spinipes).

Sexual dimorphism becomes apparent from C II onwards in Canthocamptidae and at least in Nitocra spinipes. Female and male antennules are similar in the beginning and grow more and more divergent in later stages. Antennules of females in most cases reach the adult state already in $\mathrm{C} \mathrm{V}$, whereas males normally undergo drastic changes in antennular structure from $\mathrm{C} \mathrm{V}$ to C VI. Copepodids I have 3- to 6-segmented first antennae (except in Diarthrodes cystoecus where it is 1-segmented during the nauplius phase and 2-segmented in C I). Adults have 5- to 10-segmented first antennae with no higher segment number for males or for females. New setae appear on almost all segments except the first and the terminal segment.

Comparison of the antennule of the planktonic Macrosetella gracilis with bottom-dwelling Harpacticoida reveals a few differences which are interpreted as adaptations to the pelagic realm. The antennular segments are longer in $M$. gracilis, thus increasing the length/width ratio causing a slender appearance. Segments are smooth and setae are shorter than in the benthic forms. With its 8 segments in females and 9 segments in males the anten- nule of $M$. gracilis gives an example of how the length of appendages can be increased without rising segment numbers (as among others is the case in Calanoida, where most representatives use their multiarticulate first antennae as floating devices).

From C II onwards a process bearing the proximal seta/aesthetasc-complex is present in all species studied. A second seta may develop on this process thus forming a "tritheka"-complex which is also present on the terminal segment. This proximal "tritheka"'-complex is particularly evident in $H$. minuta. According to Giesbrecht (1892) who coined the term "tritheka" such complexes are common on the antennules of Calanoida.

\section{Phylogenetic considerations}

Certain families have specific formation patterns indicative of phylogenetic affinity. In all 3 genera investigated of the family Harpacticidae for instance antennular segment formation is identical until C V (tab. 1). The 2 investigated genera of Canthocamptidae are unique in increasing segment number in one step from 3 in C I to 6 in females and 5 in males of C II (tab. 1). Canuellidae and Longipediidae share antennular characters which are unique among Harpacticoida (lowest segment number in adults; a claw-like terminal segment in adult male despite clasping of female furcal setae; no increase of segment number from C I to C II; 2 aesthetascs on the aesthetasc bearing segment in Canuella perplexa from C I and in Longipedia americana from C V onwards) and separate Polyarthra from the rest.

Among Tisbidae Scutellidium arthuri (cf. Clogston, unpubl.) as apparently S. patellarum Branch, 1974 , are the only species which split off 1 segment proximad of the aesthetasc bearing segment from $\mathrm{C}$ I to CII. Among Harpacticoida this character is

\footnotetext{
4 - antennule segment (number indicates setae and if present aesthetasc) segment with proximal aesthetasc and accompanying seta
}

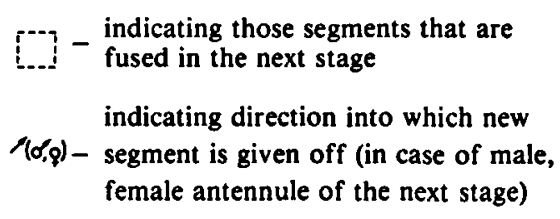

Fig. 13. Schematic diagrams of the postnaupliar development of first antennae of Ectinosoma melaniceps, Thalestris longimana, Tegastes clausi and Alteutha interrupta. 


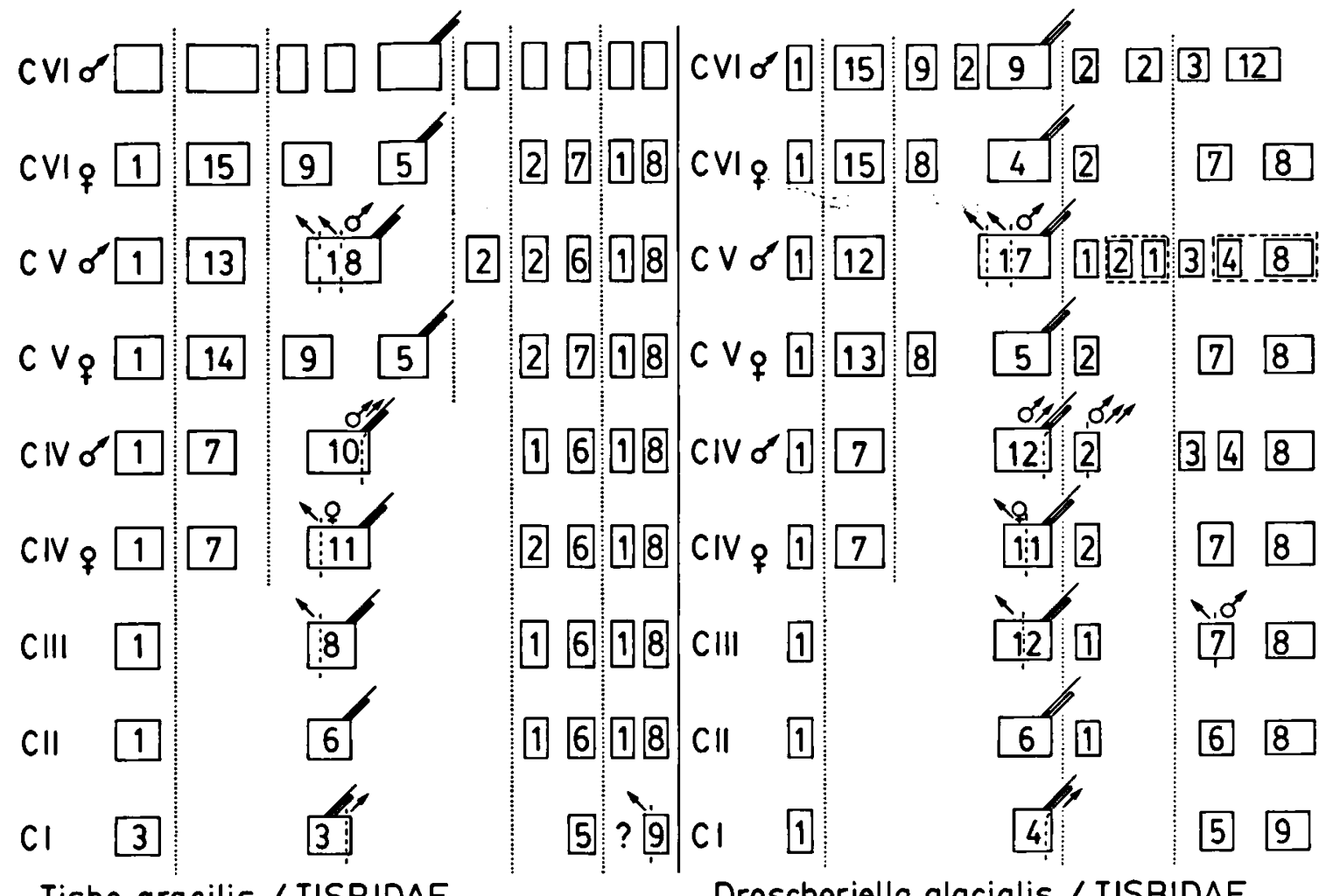

Tisbe gracilis / TISBIDAE

Drescheriella glacialis / TISBIDAE

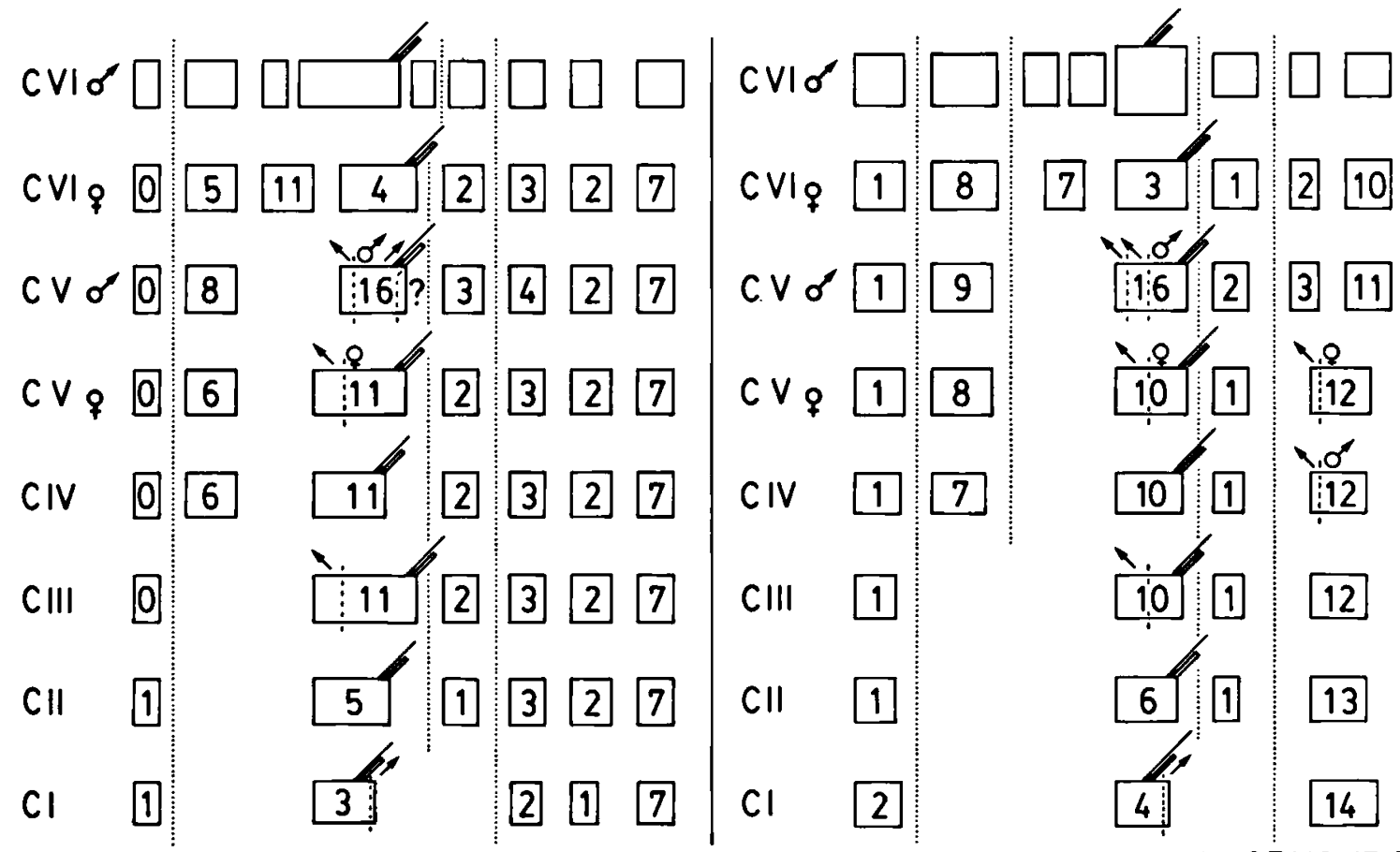
Macrosetella gracilis / MIRACIDAE

Heterolaophonte minuta/ LAOPHONTIDAE 
shared only by Porcellidiidae and places Scutellidium apart from Tisbidae.

Dahms (1988) showed that complex antennules may develop independently within Harpacticoida and suggests that male haplocer first antennae represent the plesiomorphic state within the group. This does not exclude the possibility that there are cases where haplocer first antennae may have evolved secondarily. Another point of interest is the ancestral number of antennular segments within Harpacticoida or higher taxonomic groups. It has been said that increase of the number of setae and segments during the copepodite phase only takes place in the middle of the appendage. The most proximal and the terminal segments are not involved. On the contrary, in many cases these segments undergo reductions of setae usually from $\mathrm{C}$ I to C II. Such reductions may occur on both the most proximal and the terminal segment simultaneously but this is not necessarily correlated. Reductions may be confined to the most proximal segment as is the case in Ectinosoma melaniceps (figs. 1, 13) and Tisbe gracilis (fig. 14) where 2 setae are reduced or in Heterolaophonte minuta (figs. 11, 14) where only 1 seta disappears and Macrosetella gracilis where this seta is reduced from C II to C III (figs. 7, 14). With the exception of Macrosetella gracilis all harpacticoids studied retain 1 seta on the dorsodistal corner of the 1st segment. It seems that only the proximal setae are reduced. More often, on the terminal segment 1 tiny seta on the ventral side of the aesthetasc is reduced from C I to C II (e.g. Tegastes clausi - figs. 3, 13; Alteutha interrupta figs. 5, 13; Tisbe gracilis - fig. 14; Drescheriella glacialis - fig. 14 and Heterolaophonte minuta fig. 14). Two setae have disappeared from C I to C II in Thalestris longimana (figs. 5, 13). In this case another seta on the posterior side of the terminal setae/aesthetasc complex is reduced.

Since the capacity to budd off segments and to develop new setae is restricted to the middle portion of the first antennae, it is reasonable to suggest a conservative status of the most proximal and the terminal segments. As the first segment of the naupliar antennule is devoid of setae in Harpacticoida, the 2-3 setae of the equivalent segment in C I which are reduced to 1 seta in C II would not make sense unless interpreted as palingenetic recapitulations. This does not only mean that ancestral forms in the stem line of Harpacticoida must have had more than 1 seta on the proximal segment of at least C I. For not only Gurney (1931) interpreted the presence of more setae than usual on a segment as a sign of fusion of segments. Thus it can be supposed that the ancestors of Harpacticoida had antennules with more segments than the recent representatives of this group. It remains open whether this number was 25 (as proposed by Gurney, 1931) or 28-29 (as mentioned by Boxshall, in: Boxshall et al., 1984). If one follows Kabata (1979), who places the short antennule bearing Harpacticoida near the roots of the phylogenetic tree of Copepoda, multisegmented antennules must have evolved secondarily within Copepoda assuming an ancestral multisegmented state. Tiemann (1984) emphasized that the whole taxonomy of the Podoplea centers around the number of antennule segments and that all groups of so-called Copepodoidea primitively have short first antennae. This is concluded from outgroup-comparison and from the plesiomorphic state of Polyarthra (sensu Lang). Canuellidae and Longipediidae possess short first antennae (tab. 1) but they may be apomorphic in this respect, as in other characters of this appendage (see above).
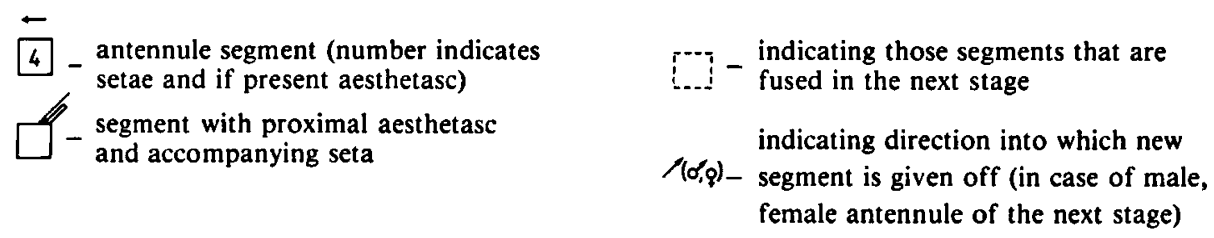

Fig. 14. Schematic diagrams of the postnaupliar development of first antennae of Tisbe gracilis, Drescheriella glacialis, Macrosetella gracilis, and Heterolaophonte minuta. 


\section{Acknowledgements}

I am indebted to Prof. H.K. Schminke for critical and improving comments on the manuscript and for his loan of developmental stages of Parastenocaris vicesima, to Dr. M. Bergmans (Brussels) for making available stages of Tisbe gracilis, and to Dr. R. Böttger-Schnack (Kiel) for copepodids of Macrosetella gracilis. I am grateful to Dr. F. Fiers (Brussels) for the identification of Heterolaophonte minuta. Special thanks are extended to the staff of the Biologische Anstalt Helgoland for patience and cooperation despite my never ending requests for service and equipment. A grant from the Studienstiftung des Deutschen Volkes is gratefully acknowledged.

\section{References}

Abraham, S. \& U.K. Gopalan, 1975. Growth of an estuarine harpacticoid copepod Nitocra spinipes Boeck cultured in the laboratory. Bull. Dep. mar. Sci. Univ. Cochin, 7: 309-318.

Björnberg, T.K.S., 1965. Observations on the development and the biology of the Miracidae Dana (Copepoda: Crustacea). Bull. mar. Sci., 15: 512-520.

Boxshall, G.A., F.D. Ferrari \& H. Tiemann, 1984. Studies on Copepoda II. The ancestral copepod: towards a consensus of opinion at the First International Conference on Copepoda. Crustaceana, Suppl., 7: 68-84.

Branch, G.M., 1974. Scutellidium patellarum n. sp., a harpacticoid copepod associated with Patella spp. in South Africa, and a description of its larval development. Crustaceana, 26(2): 179-200.

Castel, J., 1976. Développement larvaire et biologie de Harpacticus littoralis Sars 1910 (Copépode, Harpacticoïde) dans les étangs saumâtres de la région d'Arcachon. Cah. Biol. mar., 17: $195-212$.

Claus, C., 1893. Ueber die Bildung der Greifantennen der Cyclopiden und ihre Zurückführung auf die weiblichen Antennen und auf die der Calaniden. Zool. Anz., 16(423): 261-269.

Clogston, F.L., unpublished. Postembryonic development of species of harpacticoid copepods from the Pacific Coast of the United States and an application of developmental patterns to their systematics. (Ph. D. thesis. University of Washington, Seattle, 1965).

Dahms, H.-U., 1986. Zur Biologie von Paramphiascella fulvofasciata (Copepoda, Harpacticoida). Helgoländ. Meeresunters., 40: 267-277.

Dahms, H.-U., 1987a. Postembryonic development of Drescheriella glacialis Dahms \& Dieckmann (Copepoda, Harpacticoida) reared in the laboratory. Polar Biol., 8: 81-93.

Dahms, H.-U., 1987b. Die Nauplius-Stadien von Byrocamptus pygmaeus (Sars, 1862) (Copepoda, Harpacticoida, Canthocamptidae). Drosera, 1987 (1): 47-58.

Dahms, H.-U., 1988. Development of functional adaptation to clasping behaviour in harpacticoid copepods (Copepoda, Harpacticoida). Hydrobiologia, Suppl., 167/168: 505-513.
Dahms, H.-U. \& M. Bergmans, 1988. Postembryonic development of Tisbe gracilis (T. Scott) (Copepoda, Harpacticoida). Zool. Scr., 17(4): 357-369.

Dahms, H.-U. \& G. Dieckmann, 1987. Drescheriella glacialis gen. nov., sp. nov. (Copepoda, Harpacticoida) from Antarctic sea ice. Polar Biol., 7: 329-337.

Fahrenbach, W.H., 1962. The biology of a harpacticoid copepod. Cellule, 62(3): 303-376.

Giesbrecht, W., 1892. Systematik und Faunistik der pelagischen Copepoden des Golfes von Neapel und der angrenzenden Meeres-Abschnitte. Fauna Flora Golf. Neapel, 19: 1-831.

Gurney, R., 1931. British fresh-water Copepoda, I. General part and Calanoida: 1-238 (Ray Soc. London).

Haq, S.M., 1965. Development of the copepod Euterpina acutifrons with special reference to dimorphism in the male. Proc. zool. Soc. London, 144(2): 175-201.

Hirakawa, K., 1974. Biology of a pelagic harpacticoid copepod, Microsetella norvegica Boeck in Oshoro-Bay, Hokkaido. Bull. Plankton Soc. Japan, 21(1): 41-54.

Humes, A.G., 1960. The harpacticoid copepod Sacodiscus (=Unicalteutha) ovalis (C.B. Wilson, 1944) and its copepodid stages. Crustaceana, 1: 279-294.

Itô, T., 1970. The biology of a harpacticoid copepod Tigriopus japonicus Mori. J. Fac. Sci. Hokk. Univ., (6)(Zool.) 17: 474-500.

Itô, T., 1971. The biology of a harpacticoid copepod, Harpacticus uniremis Kröyer. J. Fac. Sci. Hokk. Univ., (6)(Zool.) 18: 235-255.

Itô, T., 1974. Descriptions and records of marine harpacticoid copepods from Hokkaido, 5. J. Fac. Sci. Hokk. Univ., (6)(Zool.) 19: 546-640.

Itô, T., 1976. Morphology of the copepodid stages of Zaus robustus Itô and Paratigriopus hoshidei Itô from Japan, with reference to some biological observations (Harpacticoida: Harpacticidae). J. Fac. Sci. Hokk. Univ., (6)(Zool.) 20(2): 211-219.

Itô, T. \& J.J.S. Burton, 1980. A new genus and species of the family Canthocamptidae (Copepoda, Harpacticoida) from a hot spring at Dusun Tua, Selangor, Malaysia. Zool. Jb. (Syst.), 107: 1-31.

Itô, T. \& M. Fukuchi, 1978. Harpacticus furcatus Lang from the Antarctic Peninsula with reference to the copepodid stages (Copepoda: Harpacticoida). Antarct. Res., 61: 40-64.

Itô, T. \& T. Takashio, 1980. Canthocamptus mirabilis Sterba (Copepoda, Harpacticoida) from Hokkaido, northern Japan. Annot. zool. Jap., 53(3): 210-219.

Itô, T. \& T. Takashio, 1981. The larval development of Canthocamptus mirabilis (Copepoda, Harpacticoida), with reference to the bionomics. J. Fac. Sci. Hokk. Univ., (6)(Zool.) 22(3): 279-300.

Kabata, Z., 1979. Parasitic Copepoda of British fishes. Ray Soc., London, 152: 1-468.

Lopez, G.W., 1980. Description of the larval stages of Tisbe cucumariae (Copepoda: Harpacticoida) and comparative development within the genus Tisbe. Mar. Biol., 57: 61-71.

Oberg, M., 1906. Die Metamorphose der Plankton-Copepoden 
der Kieler Bucht. Wissensch. Meeresunters., (n. F.) (Abt. Kiel) 9: 39-103.

Onbé, T., 1984. The developmental stages of Longipedia americana (Copepoda: Harpacticoida). J. crust. Biol., 4(4): 615-631.

Park, C.W., 1976. The larval development of Tisbe holothuriae Humes (Copepoda: Harpacticoida) under the laboratory conditions. Publ. Inst. mar. Sci. natn. Fish. Univ. Busan, 9: 33-48.

Rosenfield, D.C. \& B.C. Coull, 1974. Adult morphology and larval development of Paramphiascella fulvofasciata $\mathbf{n}$. sp. (Copepoda: Harpacticoida). Cah. Biol. mar., 15: 295-317.

Sars, G.O., 1904. An account of the Crustacea of Norway, 5. Copepoda Harpacticoida: 29-80 (Bergen).

Tiemann, H., 1984. Studies on Copepoda II. Is the taxon Har- pacticoida a monophyletic one? Crustaceana, Suppl, 7: 47-59.

Ummerkutty, A.N.P., 1960. Studies on Indian copepods. 2. An account of the morphology and life history of a harpacticoid copepod Tisbintra jonesi, sp. nov. from the Gulf of Mannar. J. mar. biol. Assoc. India, 2(2): 149-164.

Vincx, M. \& C. Heip, 1979. Larval development and biology of Canuella perplexa T. and A. Scott, 1893 (Copepoda: Harpacticoida). Cah. Biol. mar., 20(3): 281-299.

Volkmann, B., 1979. A revision of the genus Tisbe (Copepoda: Harpacticoida), 1. Archo. Oceanogr. Limnol., 19 Suppl.: 121-284.

Received: 11 March 1988

Revised : 24 March 1989 